\title{
Young Children's Learning about Hunger and Satiety through the Lens of the Norms of Those Who Feed Them
}

\author{
Anne Dupuy ${ }^{1,2, *} \mathbb{C}$, Sophie Nicklaus ${ }^{3}{ }^{(0)}$, Camille Schwartz ${ }^{3}$, Stéphanie Goirand ${ }^{1}$ and Laurence Tibère ${ }^{1,2}$ \\ 1 Centre d'Étude et de Recherche Travail Organisation Pouvoir, UMR CNRS 5044, CEDEX 9, F-31058 Toulouse, \\ France; stephanie.goirand@univ-tlse2.fr (S.G.); tibere@univ-tlse2.fr (L.T.) \\ 2 Institut Supérieur du Tourisme de l'Hôtellerie et de l'Alimentation, University of Toulouse-Jean Jaurès, \\ CEDEX 9, F-31058 Toulouse, France \\ 3 Centre des Sciences du Goût et de l'Alimentation, AgroSup Dijon, CNRS, INRAE, Université Bourgogne \\ Franche-Comté, F-21000 Dijon, France; sophie.nicklaus@inrae.fr (S.N.); camille.schwartz@inrae.fr (C.S.) \\ * Correspondence: anne.dupuy@univ-tlse2.fr
}

check for updates

Citation: Dupuy, Anne, Sophie Nicklaus, Camille Schwartz, Stéphanie Goirand, and Laurence Tibère. 2021. Young Children's Learning about Hunger and Satiety through the Lens of the Norms of Those Who Feed Them. Social Sciences 10: 292. https://doi.org/10.3390/ socsci10080292

Academic Editor: Nigel Parton

Received: 20 May 2021

Accepted: 26 July 2021

Published: 30 July 2021

Publisher's Note: MDPI stays neutral with regard to jurisdictional claims in published maps and institutional affiliations.

Copyright: (c) 2021 by the authors. Licensee MDPI, Basel, Switzerland. This article is an open access article distributed under the terms and conditions of the Creative Commons Attribution (CC BY) license (https:/ / creativecommons.org/licenses/by/ $4.0 /)$.

\begin{abstract}
This article focuses on parental perceptions of signs of hunger and satiety in children under 4 years of age and their effects on feeding practices, in a sample of parents of children with typical development. Discourse analysis shows the close relationships between social food norms, nutritional norms, medicalized child care norms, and educational norms in adults' determination of children's appetites according to their perceived needs and psychomotor development. The results also indicate how these norms are expressed according to social position, parental experience and context. More broadly, this article addresses top-down education-from adults to children-in food socialization, and points to the varying attention paid to the signals given by the child. It thus highlights some of the processes by which biological, psychological and social factors interact in socializing children to food.
\end{abstract}

Keywords: hunger; appetite; satiety; satiation; socialization; children; norms

\section{Introduction}

Current knowledge about the determinants of hunger and satiety in young children is based on two observations. The first concerns the innate ability of infants to control the amount of food they eat. In this case, stopping sucking and later eating when they are satiated. The second relates to the diminishment of this ability as infants get older (Birch 1990; Birch et al. 1991; Birch and Fisher 1998; Remy et al. 2015; Shloim et al. 2018) and to their socialization contexts, which are primarily studied based on parental feeding practices or interactions between the feeder and the infant. The growing interest in this area of research lies in a better understanding of the behaviors of children who are eating beyond the sensation of satiation.

The development of overweight and obesity in young children has led to a focus on the role of the caregivers during feeding. The aim is to analyze the incentives to eat more (or less) and their impact on food regulation (Remy et al. 2015; Hetherington 2017; Monnery-Patris et al. 2019). Some findings suggest that discordant parent-child interaction during a meal results in increased intake amounts and/or frequency, and impairs the infant's innate ability to adjust energy intake to their needs (McNally et al. 2016). Others question parental feeding practices. The use of pressure (forcing one's child to eat or finish a food), restriction (voluntarily limiting the consumption of a food or food group), as well as emotional feeding (offering a food to a child either as a reward for good behavior or in response to a negative emotion) appear to interfere with the infant's innate ability to respond to hunger and satiation signals (Schwartz et al. 2011). These aspects would result in accelerated infant weight gain (Di Santis et al. 2011). The "responsive feeding" approach (Perez-Escamilla et al. 2017; Pérez-Escamilla et al. 2019), which refers to a way of feeding 
that is more centered on the expressed needs and behavior of the child, is an illustration of the shifts in the nutritional management of educational feeding practices between scientific contributions and the production of public policies. For instance, in France, some recent developments in understanding the regulation of food intake are leading to new recommendations in nutritional policies (ANSES 2019; HCSP 2020). These new recommendations were based on the nutritional policy of the United States, in particular that gathered in the Feeding Guidelines for Infants and Young Toddlers included in the Dietary Guidelines for Americans. These changes may generate some norms, particularly in professional parenting support and medicalized child care.

The present research is carried out in this context of knowledge development and normative contents centered on the child. The socioanthropological angle analyzes parents' perceptions of signs of hunger and satiety or those associated with child development, in their social dimensions. This article focuses on the close links between social food norms and educational norms in the social regulation of the child's appetite and satiation, determining when the child can or should be hungry and at which moment to eat and to stop eating. The interest of a multidisciplinary approach lies in the articulation of these social processes with the psychosensory and psychomotor dimensions as perceived by the adult nurturers, and from which the feeding and food education practices are organized. The aim is to identify what, in these practices, refers to adjustments to signals emitted by the child or perceived as such, and what pertains to the social food norms internalized by the parents and implemented in an educational situation. The focus is on the ways in which dietary and educational models (in feeding) deal with the physiological (hunger, satiety, satiation), psychosensory (pleasure, displeasure) and developmental (growth, weight status) signals of the child. Additionally, how this management is deployed according to the social group, the child's sex and the parental experience, which can oscillate between reflexive or self-evident education, but also between top-down and bottom-up education.

The social regulation of feeding behaviors involved in the socialization of infants is a long-established topic in sociology (Durkheim [1894] 1981) and anthropology (Mauss 1936). In particular, research emphasizes the increments of circadian rhythms on social rhythms, which then play on the biological level through the influence of social norms on the physiological competence of infants. The socioanthropological perspective underlines the fact that these social processes affect the biological via interaction phenomena; at the level of the individual, they will socialize the biological body and the impulses (understood as psychological impulses generating motricity) and, at the level of human generations, they will participate in the expression or inhibition of genetic characteristics (Poulain 2005). The interplay between the social, the biological and the ecological is pointed out to show how eating behavior is determined in the course of development and socialization. In the dialogue with nutrigenetics and psychology, the process of expression or non-expression of certain phenotypes resulting from these interactions is shown-so are the programming of the infant's physiological competences, all the sensory-motor and sensory learnings, and table manners acquired later during socialization within social food spaces (Poulain 2002, 2005, 2017).

This article seeks to extend this analysis. In line with Matty Chiva's work on the sociocognitive, relational and affective modalities at work in child development, we are interested in the interplay between the biological, the psychological and the sociological, which is all the more significant given that the infant comes into the world in a state of incompleteness (Hubert 2000), since it survives only through total dependence on its nurturing environment (Dupuy 2017a). While this aspect is mostly addressed by examining the transition between sensation and perception from gusto-facial reflexes to the development of neophobia (Fischler 1990; Fischler and Chiva 1986; Birch et al. 1987; Pliner 1994; Nicklaus et al. 2005; Rigal et al. 2006; Rochedy and Poulain 2015), the bio-psycho-sociological co-shaping of physical sensations related to hunger and satiety is less documented. Some studies focus on the social processes that dictate when, how, and for how long children should eat (Bril et al. 2001; Gojard 2001; Poulain 2002; Ochs and Shohet 2006; Ricroch and 
Saint Pol 2012; Skafida 2013; Dupuy 2013; Lhuissier et al. 2013; Poulain 2017). Others explore further the socially differentiated modalities of incorporating and regulating physical sensations such as the expression of appetite and satiation (Le Pape and Plessz 2017). In studies focusing on the sociology of food, transmission and incorporation of normative prescriptions are viewed instead through the lens of parents' socially structured relationship to nutritional and child care norms (Gojard 2006; Dhuot 2018) in order to emphasize the early acquisition of social differentiation processes. A previous analysis of the corpus collected in our research focused on the perceptions of hunger and satiety by home-based childminders

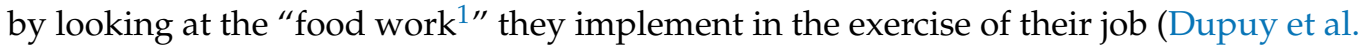
2018b). We have seen, based on other studies (Dupuy 2013; O'Connell and Brannen 2016; Dupuy 2017b; Cardon et al. 2019), that "food work" requires significant adjustments between parents and professionals. These vary with experience (professional or parental) in child care and with the gap between parents' and professionals' social positions, as these aspects affect professionals' educational positioning. Through the analysis of the "food work" contours, the teaching of social rules relating to the management of appetite and satiation-strongly emphasized by professionals - was interpreted as a way to establish a double legitimacy: both professional and social. Finally, in another article, attention was paid to the derogatory modalities involved in the interactions between the feeding environment and the infant. This focus on feeding contexts encourages consideration of the complexity of feeding relationships and educational practices (Tibère and Dupuy 2021).

This article extends the analysis of the bio-psycho-social processes involved in regulating hunger and satiety through a discussion focused on adults' perceptions (and their socially differentiated modes of expression) of such processes in the young child. The objective is to identify the ways in which parents perceive the needs and state of the young child and how these perceptions influence the "food work". The aim is also to understand the status of the child's psychomotor development in these perceptions, the evolution of the food repertoire associated with these changes, and the dynamics that shape children's daily eating practices, such as those that underlie the relationship to pleasure or the consideration of the staturo-ponderal growth, which also partly determine the control of children's appetite and satiation through their socialization. This article proposes to answer the following research question: How do standards structure food parenting practices? Methodologically, this research question involves (i) identifying norms visible in the discourses of parents (lexicometric analysis) and (ii) socially appropriate in the lived experience of their children's food socialization (content analysis and photos elicitation). This double analysis then makes it possible to identify the standards on which parents actually rely to educate their children and to discuss the process of appropriation of new standards resulting from scientific knowledge (and their use in public policies) that may go against their sense of top-down parental education.

\section{Materials and Methods}

\subsection{Study Design and Participants}

This qualitative study, based on semi-structured face-to-face interviews conducted in the respondents' homes and/or workplaces, was conducted in 2016 in France and involved 28 parents of children under the age of 4 and 25 home-based childminders. Our research is based on the analysis of the dietary socialization of children with a development considered in pediatrics as" typical ", but no exclusion criteria were, however, considered. We reconcile approaches on child development (psychology) and those on socialization (sociology) but we do, however, assume a critical perspective regarding the primacy of developmental thought, in the West, which institutes "normal" childhood.

A combination of methods for data collection were used: two interviews per family, the "photo elicitation interview" method (Collier and Collier [1976] 1986) to understand the child's diet and contextualize it (Dupuy et al. 2018a), and finally cross-interviews of parents and home-based childminders, including six parents/home-based childminders of the same children dyads. 
For initiating contact, intermediaries were sought, i.e., individuals who had either a weak or strong indirect link with the participants. For parents, the "snowball" method was adopted and combined with direct contact in parks and child care facilities with an inclusion criterion: to be a parent of at least one child aged 3 years old or less. No exclusion criteria. Recruitment was conducted directly orally or indirectly in writing by presenting the research objectives. Of the parents, 20 were interviewed twice, at least one month apart, with an average of two and a half hours of interview time per family. Each interview was recorded and then fully transcribed.

For this article, we focus only on the parental data. This is a comprehensive type of qualitative sociological survey in a view close to Grounded Theory, which breaks with the hypothetico-deductive model. Thus, the a priori definition of the number and characteristics of respondents to be selected is not subject to representativeness in the statistical sense but responds to a dynamic of back and forth and constant adjustments between research hypotheses, analytical work and the accumulation of data from the field which leads to saturation effects, e.g., when the new data no longer modify the gradually developed theoretical framework.

\subsection{Socioeconomic Characteristics}

The interviews took place mainly in the Toulouse area, the fourth largest city in France. The parents came from a variety of socioeconomic backgrounds: eight parents had a high socioeconomic status, four were downgraded (their professional status was lower than what they could expect given their level of education), nine were of the middle class, four belonged to the working class, and four were in a state of poverty.

Among the 28 families, the mothers' ages ranged from 24 to 42 , with an average age of 32 years $(\sigma=4.84)$. Fathers ranged in age from 22 to 49 , with an average age of $34(\sigma=6.51)$.

Of the families interviewed, sixteen had a single child, eight had two children, and three had three children. Of the 28 households, 24 were couples and only three were single-parent families. Of the children represented in this qualitative study, there were nineteen boys and eleven girls; they ranged in age from 5 to 48 months, with an average age of 23.7 months. Among them, three were primarily looked after by their parents, thirteen were looked after by a home-based childminder, ten were in a collective day-care center, and four were in an alternating parent/childminder arrangement at home.

The characteristics of the parents and their children are detailed in Table 1.

Table 1. Socioeconomic characteristics of participants.

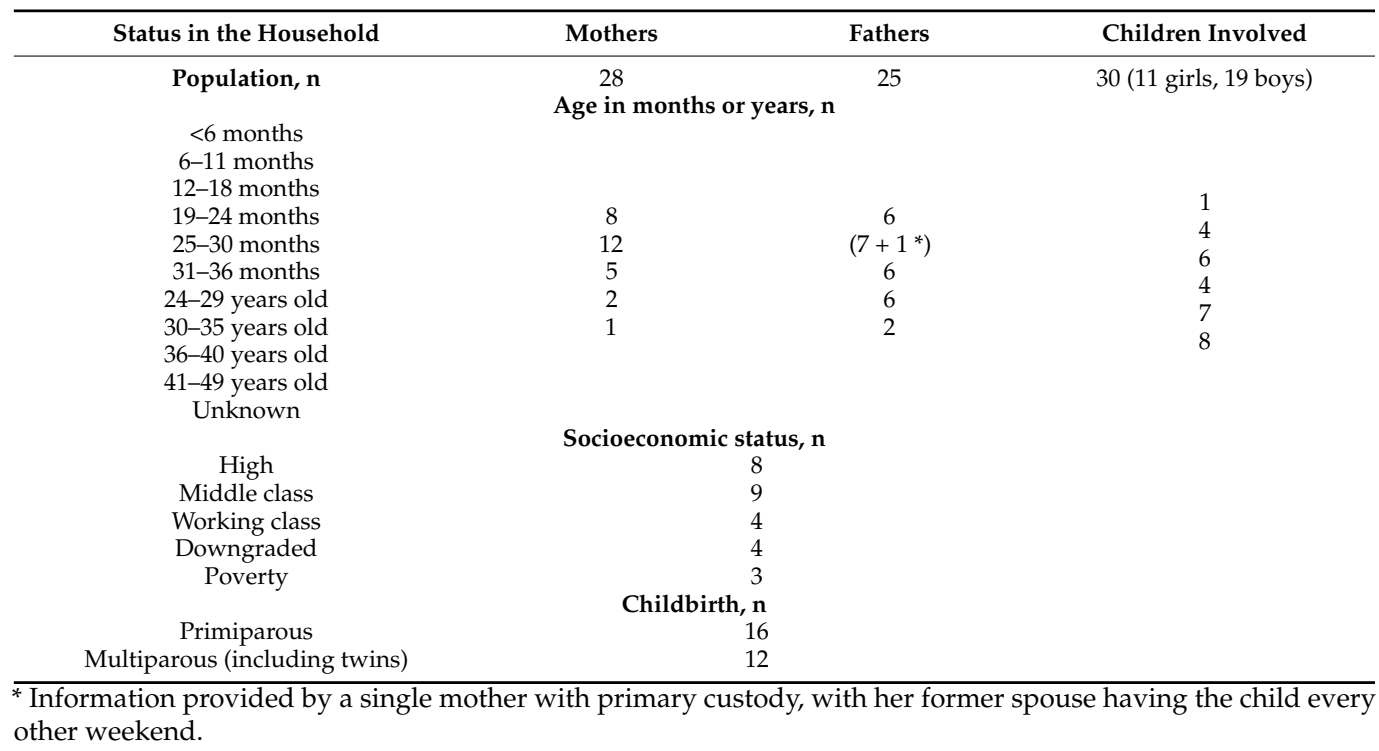




\subsection{Ethical Criteria}

The qualitative survey obtained retrospective ethical approval (N: IRB00011835-201909-24-180, Université Fédérale de Toulouse IRB \# 1). This study was also published in the CNIL declaration $n^{\circ} 2214433$. The objectives of the research were explained to the respondents and their consent for recording and obtaining the photo files was obtained. All interviews were strictly anonymous and fictitious names were given to the people interviewed. Finally, respondents were not compensated in any way.

\subsection{Qualitative Survey Material}

Among parents, the perception of children's signs of hunger and satiety was addressed in relation to (1) family characteristics (social position, composition, organization); (2) characteristics of the family diet, in particular those of the children, ranging from food shopping to the management of leftovers, by also exploring food intake (composition, quantities, frequency, duration, contexts); (3) perceptions of the signals emitted by the children; (4) the modalities of educational delegation in the field of nutrition, this term referring to the guidelines and instructions given to the childminder by the parents; (5) milk diets, then diversification; and finally (6) perceptions relating to the food educational settings (Table A1 in Appendix A). During the interviews, the parents were asked to describe their child's expression of hunger or satiety, to talk about the pace of their child's mealtimes, or to describe their child's appetite, its constancy or variations, according to different situations, such as when the child is feeling good, tired or ill. The interview guide was drawn up from the exploratory literature review and collection tools constructed in other sociological surveys relating to nutrition during early childhood conducted by some of the authors of this article. Then, the survey guide was tested in an exploratory phase and adjusted before the implementation of data collection.

For twenty households, two interviews were conducted. The two interviews were spaced 44 days apart on average $(\sigma=28.6)$. The objective of the second interview was to explore the dimensions previously mentioned while focusing on the changes and stabilities observed by the parents in the child since the first meeting. A second meeting generally leads to greater reflexivity, enabling the dynamic processes at work in socialization to be revealed. Finally, the methodological protocol allowed the parents to express themselves via photos that contextualize food intake, which anchored a number of discussions about everyday life. It is noteworthy that only the least employed parents or those from the least educated social groups refused the second interview, with the exception of one parent, who accepted the photo protocol but not the second meeting, and who was a downgraded type parent, the interview being quite demanding in terms of commitment.

\subsection{Analyses}

A methodological analysis of each interview was carried out, including the initial contacts and the exchange process. In this article, particular emphasis is placed on the gender order (Connell 1987) in early childhood socialization inquiry. A sociological analysis was also carried out, taking into account the discursive and social contexts and the socioeconomic variables. As a result, topic-based analyses of the statements were combined with lexicometric and statistical analyses using the free software IRAMUTEQ (Version 0.7 alpha 2, LERASS Laboratory-REPERE, GNU GPL License ( 2008-2014 Pierre Ratinaud, University of Toulouse Jean Jaurès, France). This software enables to cut, code and interpret speeches by lemmatization. The lexicometric analysis brings out classes of statements that are significantly connected to the qualitative survey guide (Table A1 in Appendix A). However, it is interesting to note those that move away from it and compare the distribution of "lexical worlds" (Rouré and Reinert 1993) within the corpus. The Reinert method employed in this article (Appendix B) captures the internal organization of the speeches based on the segmentation into classes represented by dendrograms and tables (Appendices $C$ and D). This method aims to identify the main themes mentioned in the corpus. Each interview is therefore divided into text segments presenting similar lexical profiles (e.g., the same 
words) grouped into discourses classes. Each of these classes is then described from the lexicon which characterizes it, which corresponds to the words significantly over-represented on the basis of a Chi2. Then, the sociodescriptive variables are injected a posteriori to study the statistical link between these variables and the discourses classes (Appendix B). The factorial analysis of correspondences gives a graphic representation of the correlations. This supports the interpretation of the differentiations identified between the classes. The different lexical registers identified are interpreted according to the methodological and qualitative content analyses conducted in the first stage; they are then used to support or discuss the statistical results (Scheme 1). The quotes from the respondents presented in the analysis correspond to quotes significantly over-represented in the profiles of the discourses classes to which they are associated.

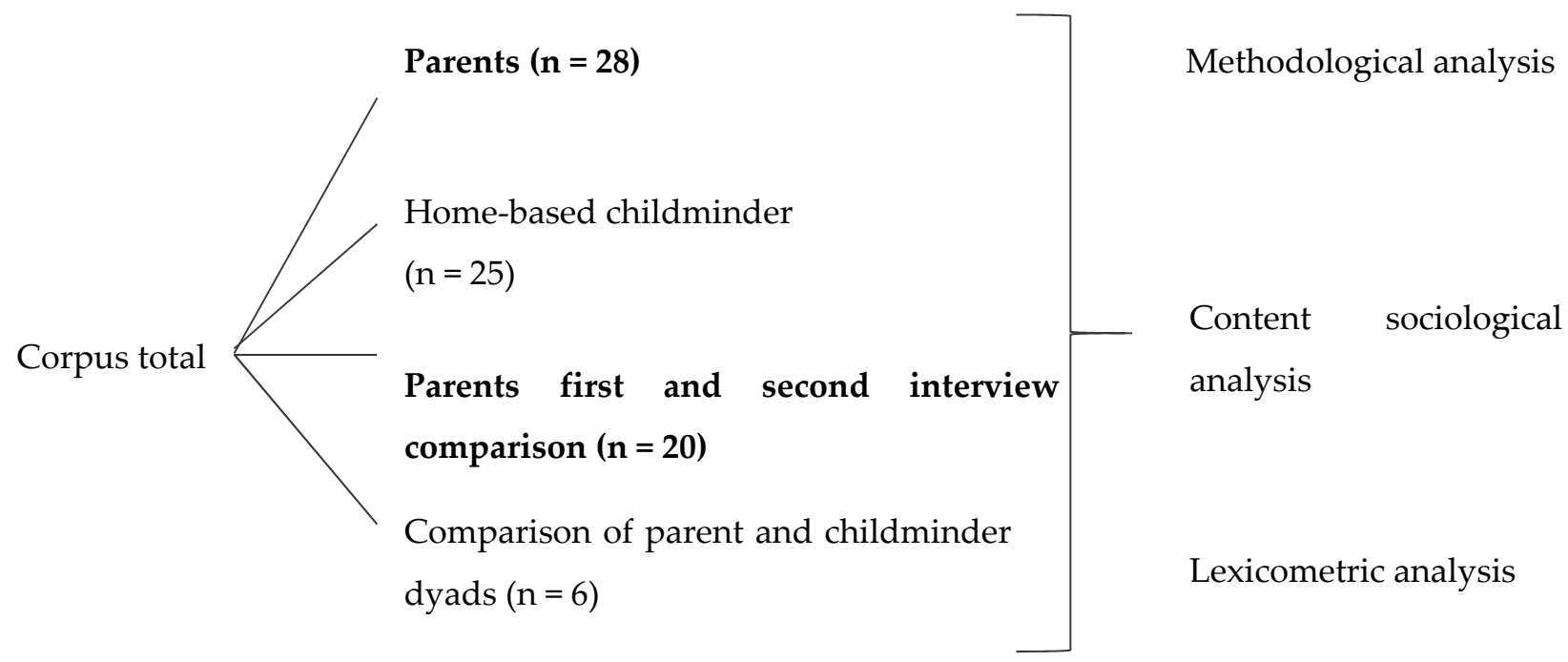

Scheme 1. Analyses of qualitative survey data (in bold, the corpora on which this article is based).

Concerning the parents, a first analysis was based on a corpus of 28 texts, corresponding to the 28 households surveyed (cf. Section 3.2). A second analysis, which was dynamic, was based on the corpus of 20 parents who were twice interviewed (see Section 3.3.1). To study the differences in the discourses classes of parents interviewed twice, a second analysis was performed comparing the discourses of the first interview with those of the second interview in order to study whether the narrative process engaged over time has effects on the discourses, e.g., relating to the perception of dynamics of change in the child's food repertoire and the expressed needs.

This textual statistical analysis was completed by a content analysis combining the photo elicitation method with the two interviews. It highlighted the various contexts in which the normative contents involved in socialization take place, based on the staturoponderal growth, the tension between pleasure and satiation, and the daily food management.

\section{Results}

\subsection{Gender Order}

Although the interview was indiscriminately addressed to either parent, only three fathers responded, one of whom responded during the second interview only. Thus, when referring to the parental corpus, it would be more accurate to speak of the maternal corpus. The lexical universes thus brought to the analysis reflect the gender order relating to the discrepancies between mothers and fathers, women and men in the division of food and care duties within the household. In this sense, they mask the gendered differentiation of parental norms and food, nutritional and educational practices that help structure children's relationship to appetite and satiation; this may be the basis for the differential socialization of girls and boys, a dimension that we have studied elsewhere (Dupuy 2017b; 
Dupuy et al. 2018b) and that was also identified in other works (Birch and Fisher 2000; Birch et al. 2003).

\subsection{The Lexical Universes of Parents}

The system of classification (Figure 1) distinguishes five hierarchical classes as follows: Classes 1, 5 and 4 refer to the social conditions of food socialization, in contrast to Classes 2 and 3, which represent food repertoires. Class 1 differs from Classes 5 and 4 in the sense that 1 refers to a parental discourse supported by the scholarly, rather medical, norms of pediatric nutrition and medicalized child care, whereas 5 and 4 refer to social norms. Classes 2 and 3 are distinct from each other in that they are based on two distinct food registers, one associated with the world of sweet foods, the other with that of salty foods. The significant relationships for these analyses are presented in Appendix C (Table A2). Correspondence factor analysis shows, on a horizontal axis, an opposition between Class 1 and Class 2, which could be positioned on a "nutritional recommendations" axis, because of the strong supervision of access to sweet foods, and a second axis where Classes 3, 4 and 5 are spread out, which would correspond to "the child's socialization to food" (Figure 2).

Class $1(22 \%$ of the content segments analyzed) includes content associated with parents' concern for medical issues, particularly nutrition, at various stages. Parents with the highest levels of education and income and whose children are followed by a pediatrician and a general practitioner are more strongly represented. This class-which we call "Relating to the medical" - relates significantly to body weight (in the sense of losing weight), height, anxiety, issues, reflux, concern, and girls. The medical dimension is present with significant occurrences of the following words: health, curve, pediatrician, doctor, notebook, general practitioner, growth, allergy, weight, vomit, body, sick, as for this respondent, statistically over-represented in this class.

"When I come home from the doctor, that's the first thing I do, I graph. It's something I love, I always look forward to graphing, I don't know why, but it's seeing if they're progressing well, tracking, I don't know. Yes I look to see if they're in the norm. And they are pretty much in the norm". [Mother ( $p<0.0001$; Chi2: 43.08), high social position, 4-year-old daughter and 11-month-old boy].

Recommendations for dietary diversification are based on timelines, which combine the child's age (in months) and the diversification of the food repertoire. They are proposed in numerous channels or media, ranging from medical follow-up by a pediatrician to communication by the food industry, including child care facilities in services dedicated to early childhood. The dissemination of these recommendations has intensified with "nutritionnalisation" (Poulain 2009), a process of thinking about one's relationship to food through a purely nutritional lens. These recommendations are thus easily accessible to parents from all social backgrounds, even if they are not always followed and viewed as legitimate (Gojard 2001; Gojard 2010; Régnier and Masullo 2009; Depecker 2010). In addition, many studies confirm the importance of nutritional recommendations during the transition to parenthood, particularly for a first child and during the first months of life (Anderson et al. 2001; Corbeau 2010; Dhuot 2018; Moura and Aschemann-Witzel 2020). 


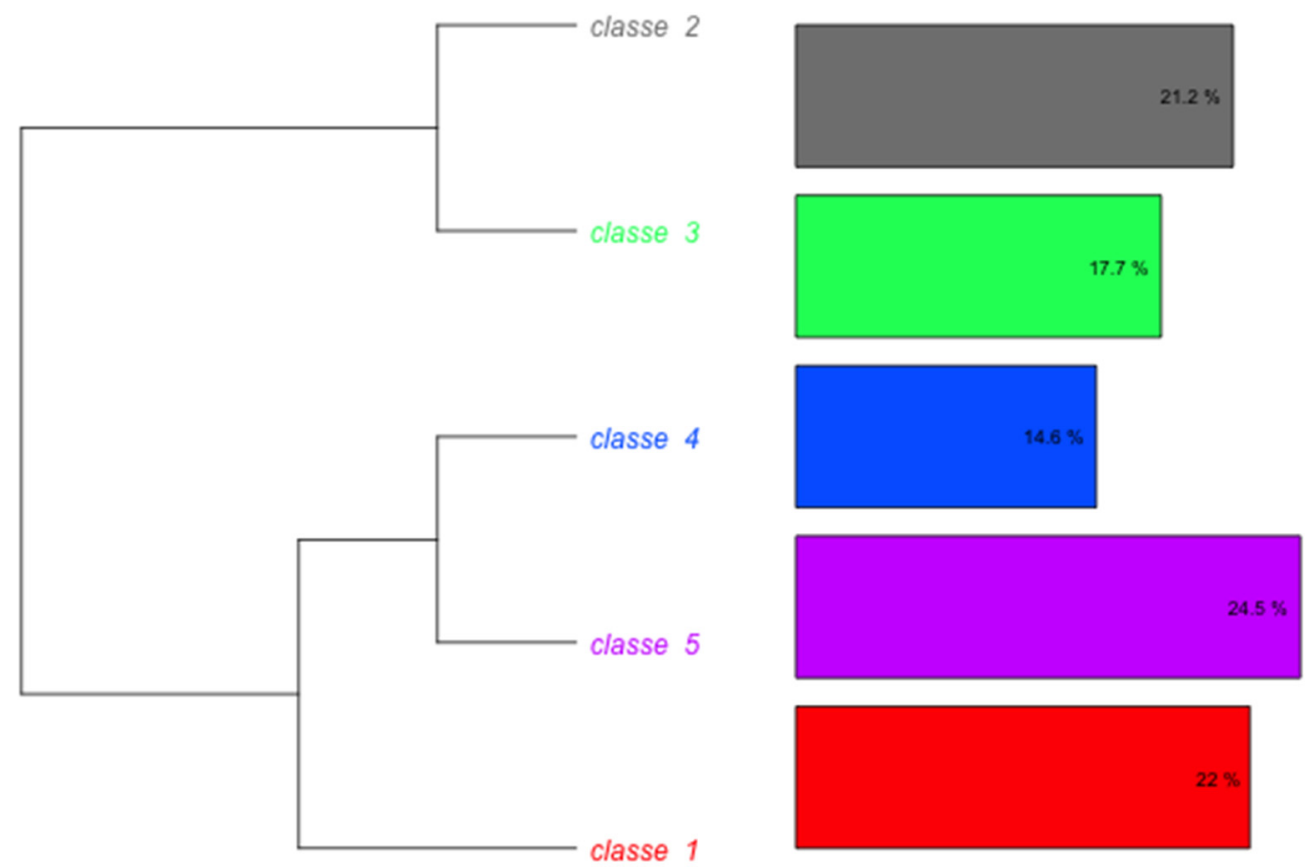

Figure 1. Dendrogram—-parental corpus.

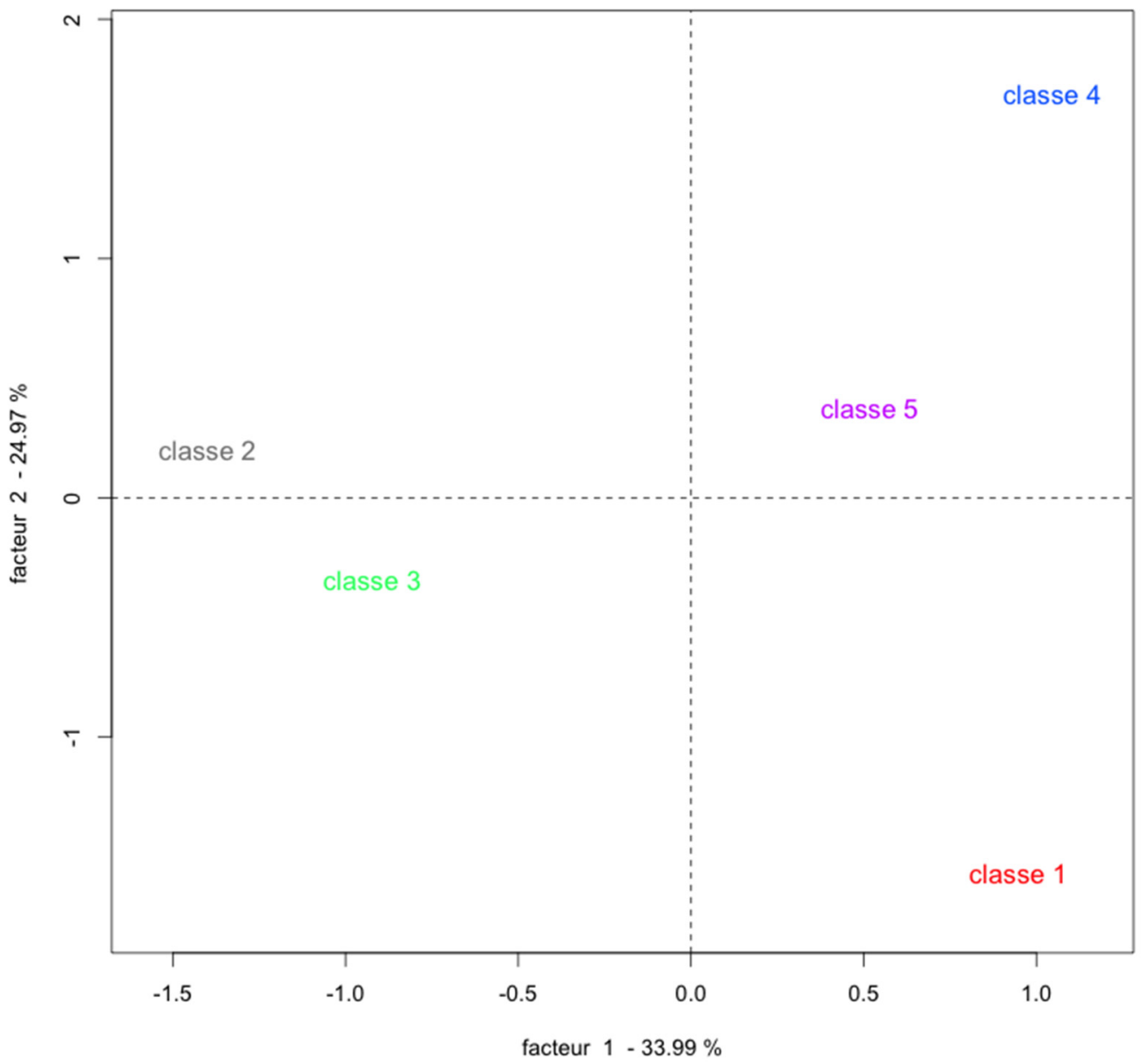

Figure 2. Correspondence factor analysis based on Reinert's classification-parent corpus. AFC of the two dimensions summarizing the most data-factor 1, eigenvalue: 0.29 ; \%: 33.99; factor 2, eigenvalue: $0.21 ; \%: 24.99$. 
Class 2 (17.72\% of the content segments analyzed) overlaps with lemmatized forms designating the purchase or consumption of sweet foods when desserts or snacks are mentioned. This class illustrates the "relationship to the sweet food repertoire" of parents with respect to their children, particularly in terms of how they manage their appetite for sweet foods. The structure of meals is a social organization of food intake that gives dessert a particular status as the end of the meal, which serves as the finale of the meal (Tibère and Dupuy 2021). The social organization of the end of the meal, which is often sweet, is transmitted to and processed by young children during their socialization. They thus learn to regulate their consumption according to a dietary time frame. Dessert is also a technique used by adults to regulate food intake of simple non-carbohydrate nutrients and ensure that the child is properly fed. Class 2 also refers to afternoon snacks, which in France remain resolutely associated with the sugary, pleasurable, and indulgent world (Diasio 2006) despite certain nutritional recommendations that promote the "cereal + fruit + dairy" formula (Tibère et al. 2018). More than the other meals of the day, the afternoon snack is organized according to the child's desires and, implicitly, those of the parents (Dupuy 2013), which reminds us how mothers' eating habits and preferences can affect their children's diet (Dhuot 2018). This class reflects an attraction to sweet foods, such as chocolate, cakes, sweets, sugar, which are prevailing among parents with the lowest levels of education and resources, even though many mention their control over the purchase and consumption of industrial sweet products.

Some parents wonder about the links between their children's attraction to sugar and their preferences.

"And then, does it matter or not, I have a sweet tooth, so obviously I ate a lot of sugar during my pregnancy and that may have had an effect, but I don't know if there is a link. So since I tend to eat more sugar, maybe I got her used to sugar" [Mother, middle-class social position, one 33-month-old daughter].

Pictures 1 and 2: Daily situation: Meals and leftovers, 11-month-old girl Mother, working-class social position ( $p=0.00065$; Chi2: 11.62).
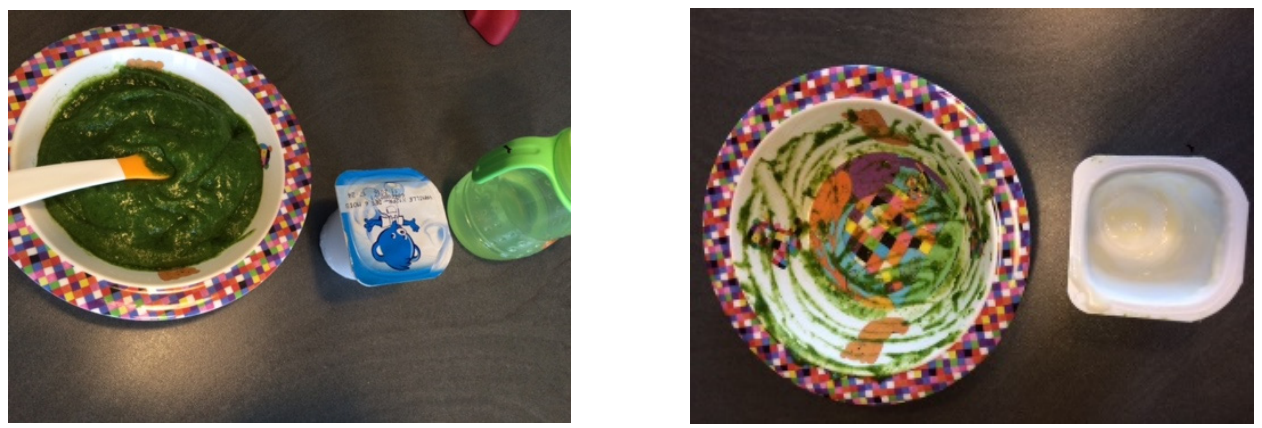

"White chocolate, I made her taste it. Even I tasted it, I thought it was really good! The first time I gave her some, I even opened a second jar for her because she gobbled it up! I thought "oh great!" ( . . . ) And she loved it, I gave her a second one, although she didn't finish it, but that's normal! ( . . . ) But it's true that I tended to do that at the beginning and when she discovered the different cream desserts, when she had finished and kept opening her mouth, I would open a second jar. But she would never finish it, it was mom who finished it".

Among parents from middle-class backgrounds, dessert and afternoon snacks are characterized by a preference for fruit and fruit compotes, preferably organic or bought at the local market, as well as dairy products such as yogurts and cheeses. As for sweet foods, they are mentioned in relation to the control that parents maintain over their child's consumption, or even their refusal to buy them. Thus, this class is rather characterized by a discourse expressing control, or even rejection, of the consumption of sugar or sweet products, with the exception of naturally sweet products such as fruit and compotes. We find this idea in the following remarks: 
"And then on top of that I don't want to buy ... anyway, there are organic ones but they are sweet and I find that insane, all the "baby" products are sweet, it's crazy!" [Mother, middle-class social position, 7-month-old boy].

"Yes, they love compotes, so I buy them, I get them without added sugar because I tell myself they are small anyway". [Mother, working-class social position, 14-monthold boy and girl twins].

"They make this organic stuff with oranges, well, stuff without sugar or anything, it suits him very well, I mean he can tell the difference". [Mother, middle-class social position, two boys aged 29 months and 4 years].

Class 3, accounting for $21.21 \%$ of the corpus segments, is associated with two registers: the ingredients present in purees-especially when parents refer to diversification-and the main courses at lunches and dinners. Discussions include vegetables, such as carrots, tomatoes and zucchini, as well as starchy foods such as pasta or rice and animal proteins such as meat or ham. This class is called: "relating to the salty food repertoire" and involves a parental discourse centered on cooking preparations, recipes or proposed meals or a nutritional discourse of attention focused on dietary balance, the presence of certain nutrients during a given meal or day, particularly concerning the alternative "animal or vegetable products". This class is significantly associated with parents reporting an important concern for nutritional or medical recommendations, having a daughter and having a high level of education even if the level of resources, compared to the level of education, is low.

Pictures 3 and 4: Daily situation: Pea puree and leftovers offered during the interview Mother, high social position, two boys aged 5 and 29 months ( $p<0.0001$; Chi2 26.54).
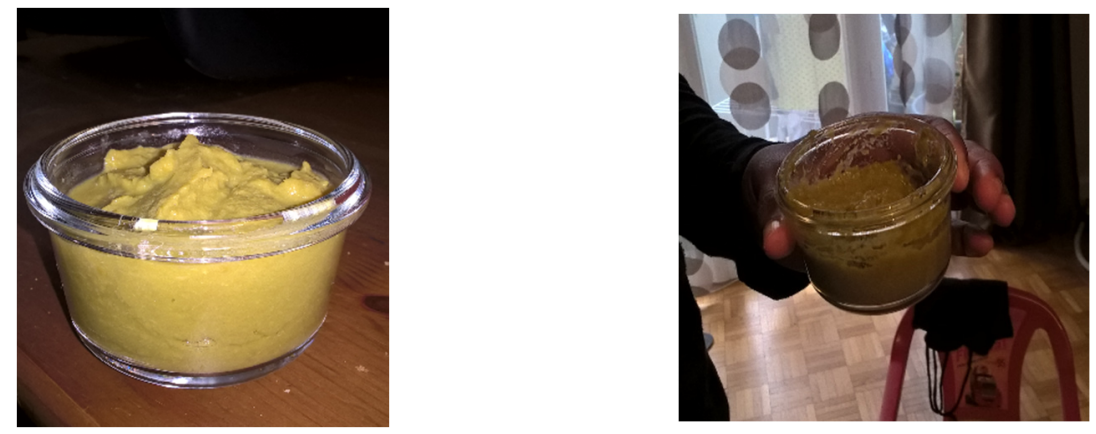

Mother cooks mostly vegetables for her boys who eat no meat in the evening and on weekends.

"In terms of vegetables, he eats everything. Yesterday, he ate parsnips, and my grandmother said, "But parsnips are disgusting;" well, he liked them. Anyway, it was not too strong, it remained bearable, he ate, he ate everything. (... ) So what works immediately is green beans, peas, that goes down really well, and ... So the sweet potato last time I made it a little too thick, so it was weird, so it didn't go down well ... But beans, peas, and also leeks go down well.

[Interviewer: And you use leek alone?]

Yes, only leeks. I don't put a lot of potatoes, in fact, because I was told that with vegetables, for the taste, it was better not to put too much potato. And he likes it. (...) So it's strange because the first time I made him taste peas I had put green beans too, so it's actually the first time that he is eating plain peas, only peas. It seems to be going well. Okay, there's a little bit of a funny face though ...

[A few minutes later] Will you close your mouth? You cheeky boy! Eliott? I'm going to try the little train again, "Eliott, choo-choo" [she makes the little train with the spoon to his mouth], does it work? Well now I think that... Well, you've eaten a little more than half of it, that's not bad!" 
Class $4(14.57 \%$ of the content segments analyzed) corresponds to "the temporal framework of food socialization". This register does not so much refer to learning by children, who are themselves subject to social conditions, as to the way in which parents organize themselves to incrementally set food rhythms. This class sets schedules for food intake and meals and by modifying responses to their children's physiological needs. Parental learning about feeding management, with the sleep cycle of newborns and infants, is addressed: there are, for example, references to the words morning, evening, night, noon, wakes up or time.

This class significantly includes parents who declare that their child is followed by a pediatrician, parents with a middle-class social position, parents with a medium level of education and resources, and less significantly among parents with a low level of education and resources and primiparous mothers. This class is titled: "temporal framework of food socialization" as illustrated in the following interview extract:

"And for the afternoon snack it's the same, he has always been used, since he was little, to having a snack when he gets up from his nap. So when he gets up, he says "let's go and have a snack". But I think it's more out of habit than hunger. It's because he's used to it that when he gets up from his nap, he knows he's getting a snack. But other than that, we try to make sure he eats at fixed times". [Mother, intermediate social position, a 30-month-old boy].

Class 5 (24.48\% of the content segments analyzed) is associated with the "social framework of food socialization" in particular with learning table manners. It is characterized by the occurrences of the following words: table, play, hunger, meal. In this class, the regulation of appetite is learned within meals and not through eating outside of meals. This reminds us of how important the acquisition of social practices related to food is. Mealtime is a space for the acquisition of table manners, based on parental and professional educational practices as in the following interview extract for this mother of high social position who "teaches" her education through play. These include the ways of behaving at the table, which vary according to what adults and their social norms consider appropriate or inappropriate for the child's age. During their early socialization both within and outside the family, children internalize these norms by imitating adults and other children. Getting children to eat "well" is an educational challenge. Here, again, there are different possible strategies from parents and different attitudes from children depending on social and cultural backgrounds that influence educational and family models as well as adjustments during interactions.

"With the green puree, when he played with it, when he dipped his hands in it, I thought it was so cool. It was carnage, I was painted, the floor, his chair too. But he ate it all. He played with what he had on his hands. And I thought, "I'm never going to get mad at him when he does that, I'm going to let him do that, that's cool". We also agree on this point of view, we are not going to ask him at 5 months to eat properly. As long as he wants to put his hands in, he will". [Mother, high social position, 7-month-old boy].

Picture 5: Daily situation-Meals and leftovers of a 7-month-old boy, Mother, high social position ( $p=0.00381$; Chi2 8.37). 


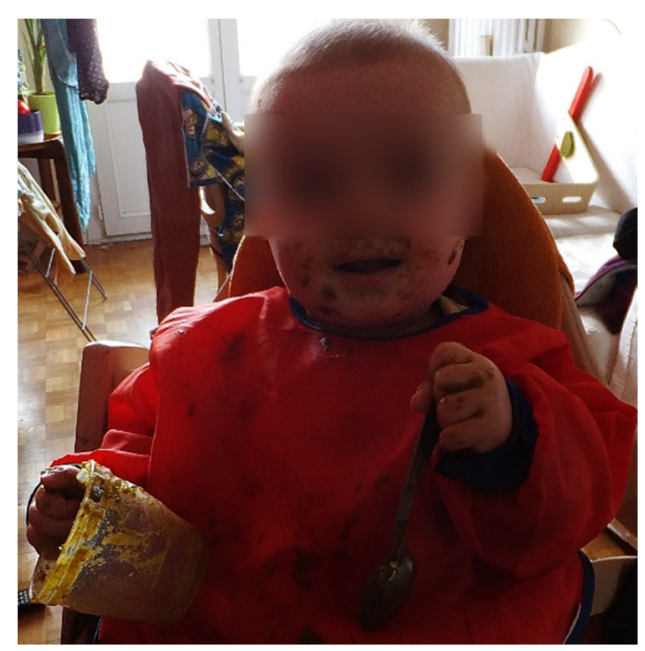

"No, I still hold him, but I don't want to get into a fight with him, and since I can tell he wants to play with the food, I bought him an apron with sleeves and I let him put his hands in it. [ ... ] [commenting on the photo] Yes, he puts some in his hands and has fun closing his hand, so it comes up and it makes him laugh. Because with diversification, I read that it's good for him to know the shape of the food, so I think I'll put some well-cooked pieces in his puree so he can touch and know the shape of the vegetables". [Mother, high social position, 7-month-old boy].

The educational practices of adults are shaped by the adjustments that occur in interactions with children (Laurier and Wiggins 2011). Moreover, the use of play depends on the level of tolerance for the playful register at the table or when eating (Corbeau 2008; Lalanne and Tibère 2008) as well as on socially differentiated conceptions of childhood (Lahire 2019).

"I don't force him, if he doesn't want to, then he doesn't want to. We take a little break with a toy and then he eats the rest". [Mother, high social position, 7-month-old boy].

Young children's difficulty in controlling their bodies and resisting the urge to move is reflected in their parents' remarks, especially when the child switches from a highchair to a regular chair. In some families, these chairs are used alternately, giving the child some flexibility and allowing for a quiet meal in the evening. With the exception of the parents who are downgraded and belong to the "cultural capital" (Bourdieu [1972] 2000) and who teach table manners, Class 5 is over-represented among the parents of a modest social position and with a low level of education and resources, who mainly mention the playful and convivial aspect of this learning. This aspect, while it may reflect a bias of social attractiveness, may also reveal educational strategies used by these parents to establish a certain "respectability" in food education, as highlighted elsewhere (Le Pape and Plessz 2017) through the teaching of a legitimate rhythm, in this case the duration of the meal as we observe in these two parents.

"We don't let them play with food much, the only time is with the letters that are in the soup but otherwise, no, not at all". [Father, middle-class social position, one boy 48 months old, two girls 5 and 10 years old].

"Well, for her age, she knows how to behave, she is not messy, she eats well with her spoon. Then I'm probably too manic but it's something I can't stand. She doesn't play with the food, she doesn't spit with it, and when it's too dirty I tell her "wait, settle down and only then we'll eat more". But she eats well, she is clean, sometimes she will play with the ham, but I tell her "it's not very nice, we don't play with the food", she is quite clean and delicate, she doesn't run around too much". [Mother, middle-class social position, 30-month-old daughter]. 


\subsection{Perceptions of Hunger and Satiety: Social Dynamics of Adjustment}

The content analysis, focused on practices and based on interviews and photos, highlights three complex determinants involved in the perception of hunger and satiety as well as their links to educational norms and models: the dynamics of the child's growth linked to the evolution of physiological, social and emotional needs; the dynamics of hunger and satiety associated with pleasure and the management of desire; and finally, the dynamics of daily preparation practices and routines that question the evolutions in textures and portions.

\subsubsection{Growth Adjustment Dynamics}

As children grow in size and age, their physical and physiological characteristics change. Adults-both parents and professionals_-adjust their diets to these characteristics.

These dynamics can be seen in the lexical analysis of parental discourse. The comparison of the two corpora spread over time shows changes between the first and second interviews, as a result of changes perceived by the parents in the child's sensorimotor and psychomotor development; the perception of these changes leads to responses regarding feeding.

When comparing the discourse during the first interview (Figure 3) with that of the second (Figure 4 and Table A3, Appendix D), the classes relating to the foods consumed (Class 1' "relationship to the salty food repertoire" [16.5\%], and Class 3' "relationship to the sweet food repertoire" $=[n=29,3 \%]$ ) contrast more visibly with Class 4 " "temporal framework of food socialization" $(15.35 \%)$ and Class $2^{\prime}$, a new class that illustrates the greater attention paid to the child in terms of "perceived evolutions in child development" (38.9\%) with words such as child, month, curve, weight, girl. These results show changes in the parents' discourse classes between the two interviews and reveal a focus on child development. However, although perceptions relating to this dimension emerge in the discourses, they seem to be less associated with responses to the signs of hunger and satiation expressed by the child than with internalized normative patterns. The class "perceived changes in the child's development" appears in the second interview precisely because a period of time occurred between the two interviews, letting changes take place in the child's diet and expressed needs, and also letting the parents learn to identify them. Therefore, the occurrence of this class results from the methodological protocol as well as from the questions and reminders proposed by the interviewer. It seems that these feeding practices are less the product of an adjustment to changes and signals perceived in the child than the result of a distinct temporal order and the mobilization of top-down educational models, which are themselves rooted in feeding models. Furthermore, the discourses that propose listening to the child's rhythms and needs, and trusting the child's ability to express them, correspond more to a rationalization in front of the investigator than to spontaneous educational views. Finally, the fact that no marked social differentiation is visible for this class indicates that this educational model is present in all social backgrounds with a $p<0.0001$, even if the chi2 for the high social position is a little stronger (50.66) against 40.23 for the more modest social positions. 


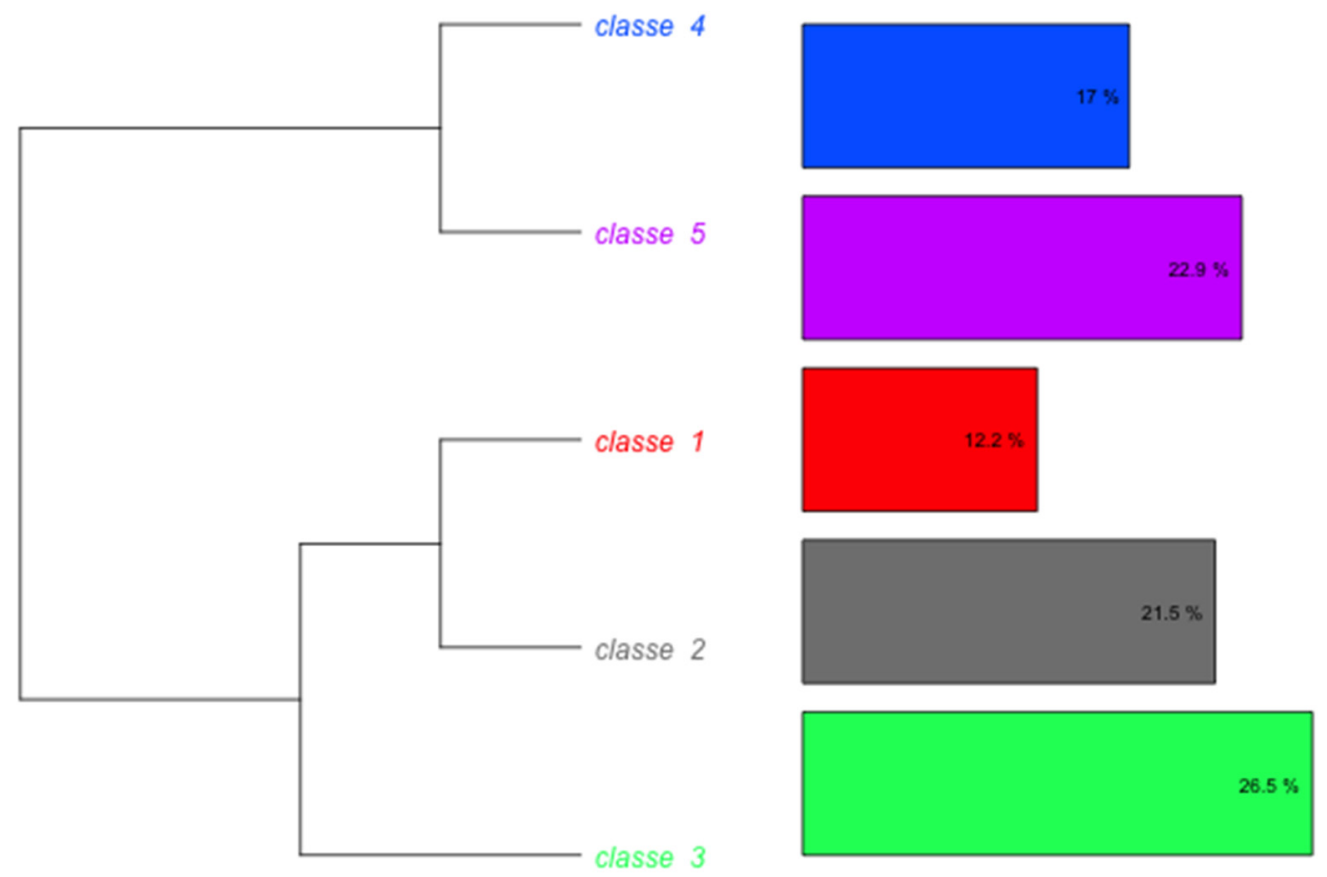

Figure 3. Dendrogram-first interview-parents.

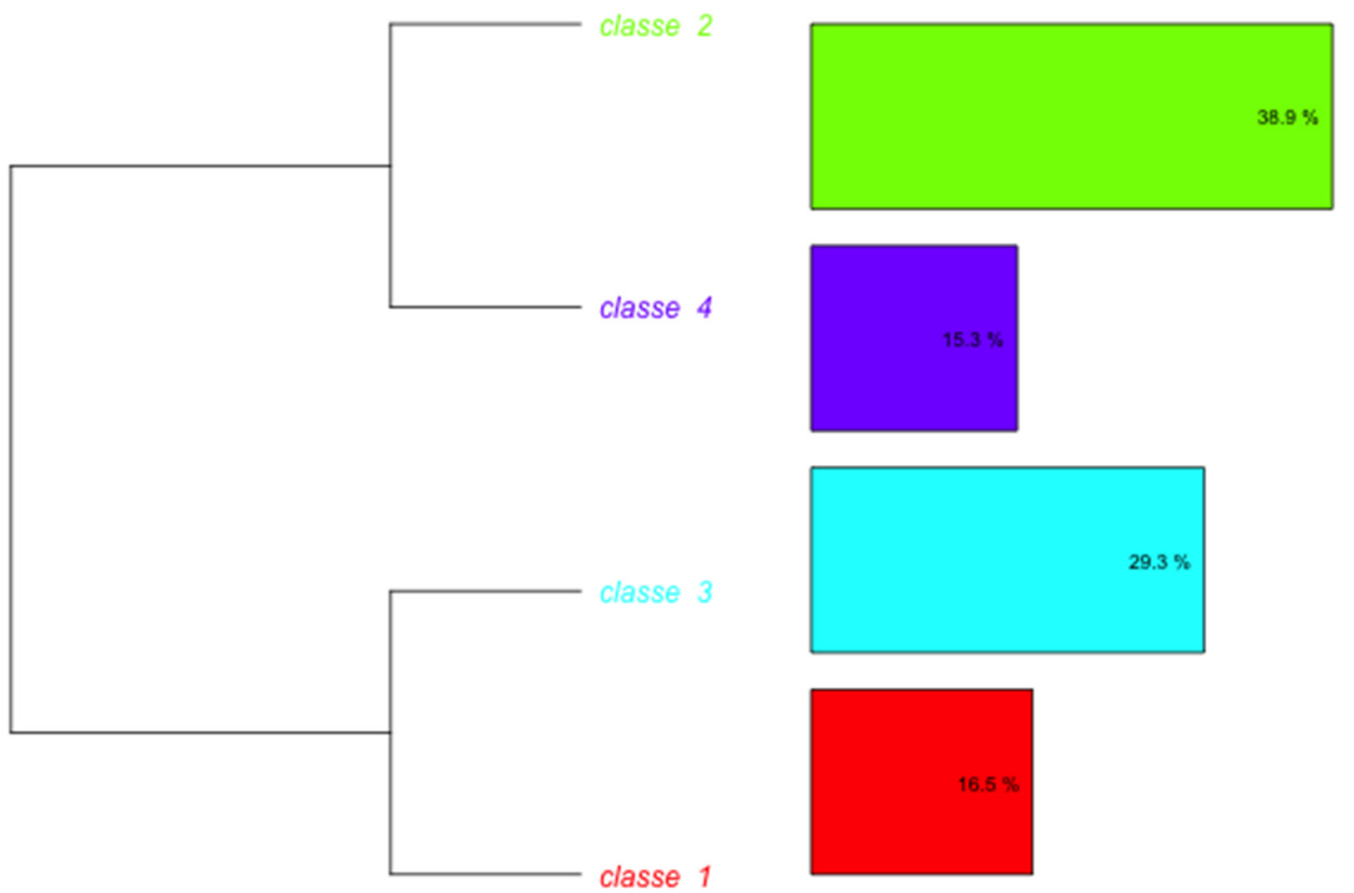

Figure 4. Dendrogram—second interview-parents.

The staturo-ponderal growth is an indicator that adults rely on in order to adapt the amount of food served, as expressed in Class 1 (see Section 3.2) and Class 2'. Parents also rely on the evolution of their child's weight-height curves, which is recorded during medical consultations, or they refer to age-related food guidelines. This staturo-ponderal growth is assessed subjectively in comparison to the staturo-ponderal growth running in the family, particularly that of the parents and siblings, but this assessment is also based on a wider family circle. As a result, comparisons start linking the family's growth experiences and the evolution of the child's body. They also correspond to socially differentiated somatic cultures. These elements are likely to determine both what is given and how much is given to the child (Nicklaus et al. 2019). Some studies have also shown the impact of 
the mother's weight experience on the restrictions placed on children, particularly girls (Birch and Fisher 2000; Birch et al. 2003; Bournez et al. 2018; Hetherington 2017). This is this situation we encounter with this mother:

"I would go to the doctor and follow the advice because in fact as a child I was fat and it used to be annoying. It wasn't a disease but it was just a little bit like it ... it annoyed me because it was harder to make friends, they said I looked like a meatball so it was more like that. But it wasn't about my health, it was just annoying". [Mother, downgraded social position, 36-month-old boy, 6-year-old girl]

However, if the evolving growth of the child is rooted in family standards, its transformations are an object of a social gaze, whether approving or disapproving, that defines and shapes it to a large extent, just as do the practices of early childhood professionals described by Delphine Serre (1998). When documented in the child's health booklet, the evolution of the child's weight and height curves allows parents to evaluate their child's development in comparison to a staturo-ponderal normality set by medical institutions. The parents then look at their child's changing body and whether or not it falls within the curves of "normal" development. The child's biological body is a social body (Diasio and Vinel 2017). In our societies, the changing body of the child is considerably medicalized and is the object of monitoring devices, especially during the first days and months of life. André Turmel (2008) has shown how physical and psychological measurements, thought of in terms of maturation, set developmental standards that help to socially organize growth, aging and body transformation. In this way, this process of normalization also contributes to establishing a normality and an abnormality of growing up, particularly expressed in our qualitative study in relation to children considered too thin.

As has been shown (Turmel 2008; Diasio and Vinel 2017), the child's age is also a relevant and legitimate criterion to enable the evolution of the dietary repertoire (in terms of content, texture, and quantity) to be assessed according to the child's needs. The biological age, on which the recommendations are based, acts as an identification marker. Expressed in months, the schedule of food diversification distributed in many child care media contributes to naturalizing the biological age of the child by making it the objective and objectifiable variable (in the sense that it is measurable) to base the evolution of the food repertoire. This repertoire also depends on social and institutional definitions of childhood; those definitions are linked to specific institutions that mark the various ages of life. For instance, the start of schooling, which in France occurs around the age of three, helps to socialize children into integrating food models and table manners through bodily dispositions that prepare them to be hungry when it is time to eat, and to feel satiated at the end of a meal. These perceptions may be objectified by the medical profession on the basis of growth curves, or they may remain attached to family memories. They can also be shaped by professional practices or by both institutions and the norms they disseminate concerning the child's social body. They affect the food and the quantity of food that parents offer their children. They also influence the ways in which food is accessed and controlled, especially for children in the lower and upper curves of our corpus.

However, the child's advancement in age and the physiological changes that come with it, even if they remain a relevant category, are not without socially differentiated interpretations. We have thus shown that the professional experience and social position of home-based childminders set up a distance from child care norms, particularly concerning the diversification stages perceived as dietary fads by the most senior professionals in the field (Dupuy et al. 2018b). This distancing may affect parenting practices by changing them. In another study, the polysemy associated with the notion of "specificity" of child feeding was questioned by showing that, among parents, specific feeding for their child does not only concern the foods or ingredients offered but also the textures, the quantity, the quality, and finally the material, temporal, emotional, and social contexts-places, times, duration, and interactions associated with food intake (Dupuy and Rochedy 2018; Dupuy et al. 2018a; Wiggins 2019). Furthermore, biological age can be socially reappropriated, but this reappropriation always occurs within a time window defined in medical 
recommendations for initiating diversification (Bournez et al. 2018; Dhuot 2018) like what is expressed here.

"[Interviewer: But on the progression of the quantities?] As we went along, we added little spoonfuls; in the evening we would obviously add less than at lunchtime. For example, when he was still eating a mixed diet, I tried to give him a little less than at lunchtime, because at lunchtime he was obviously hungrier. [Interviewer: And in the evening?] I would take a little bit off, but in the evening, he would ask for less. [Interviewer: Did you do this because you realized that he was eating less in the evening or was it by anticipation?] Because we were told to eat a little lighter in the evening. [Interviewer: Is it your pediatrician?] Yeah, I think it says that, on the back of the sheet". [Mother, middle-class social position, 21-month-old boy].

The implicit developmental logic that underlies this process, which prevails in our societies, and the norms that are associated with it, particularly through medical institutions, confirm the logic of physiological development (in particular the maturation of the digestive tract) and psychomotor development in feeding the young child. This double implicit effect also modifies the food repertoire and notably the quantities served so as to transform the physical and physiological characteristics of the child. In this case, it is the child's "healthy growth" that is targeted, which implies differences in perception according to social origin, experience or even the family's staturo-ponderal experience. Certain foods, such as dairy products, are served in greater quantities to encourage growth, although sometimes drifts such as the lipophobia identified in certain social environments, has the effect of reducing children's access to fats (Bournez et al. 2019). Those drifts are sometimes reflected in our corpus. Moreover, what looks like an approach aimed at a child's "healthy growth" is also accompanied by the idea that successful growth is a guarantee of a child's progress through developmental stages. This link between growth and psychomotor progression results in some parents, especially mothers who are concerned about dietary standards, seeking to optimize the food repertoire and the quantities of food available. Vegetables, dairy products, fruits, oils and fish are labelled as "superfoods", especially when they are organic and cooked from raw at home, as with this interviewee.

"I always followed the doctor's recommendations to the letter. As it was the first one, I acted as a really anxious mother: it really mattered that there was a spoonful of oil! In the mashed potatoes! If I forgot it, I made him drink it! No no, it was really important, everything had to be there. And then I introduced a lot of vegetables very quickly, he always ate everything, he always finished his plates, he was a good baby, a big baby". [Mother, downgraded, two boys, 18 months and 4 years old].

The growing child's body is subject to family, extra-family, or institutional assessment and monitoring that affect the amounts of food being served and allowed.

\subsubsection{Deciphering Pleasure and the Dynamics of Satiation Adjustment}

The perceptions of hunger and satiation are also determined by the dynamics of satiation and pleasure perceived by the caregivers. Mention of the sick child is strong in this category, as the illness always illustrates the lack of appetite for food and the return of pleasure, and the recovery from illness. In this case, there is a greater tolerance for the quantities that are eaten, as well as for the type of food and the way in which it is eaten like here:

"And in the evening, after he had a long day ... I never bother, I offer him something to eat, he doesn't want it, I give him his bottle of milk and he goes to bed." [Mother, middle-class position, two boys aged 36 months and 6 years].

The most relevant context in which this dynamic appears is the way in which both adults and children deal with the tension between pleasure/satiation on the one hand and social norms and rules on the other. The management of sweet products is emblematic of this tension as here: 
"It's not a problem. And then if he doesn't want to finish his plate, he doesn't finish his plate, it's not an issue. There are little rules that we apply, that is, there is no dessert if there is no proper meal". [Father, high social position, daughter 7 months and son 4 years].

"But if he ate three carrots and then wants an ice cream, that's not gonna work (chuckles), but if he had three bowls of soup and then wants an ice cream, yeah ... Not like the American way, I mean eat whenever you want, but it's ok to eat as much as you want in the time dedicated to meals". [Mother, middle-class position], two boys aged 36 months and 6 years old].

Eating rhythms set physical dispositions in children by transmuting hunger into appetite (Bourdieu [1972] 2000). The social organization of food intake also provides a reference point for children and the adults who feed them. The following extracts show this learning of parents.

"I can tell the difference, because we got him used to eating at a certain time. So I could see when he wanted to eat and was hungry". [Mother, low social position, 23-month-old boy].

"But then they are so set in their ways, the bottle is at such time, the meal at such time, that you are used to it, you know your children and you don't think about it. If he cries, it's because he's hungry, if you arrive at 11:30 AM and there are cries, it's because he's tired and hungry, because then it's time for a nap. And if it's not that, it is often because they are sick. It's pretty easy to feel these things". [Mother, middle-class position, two boys aged 36 months and 6 years].

Within a feeding sequence, especially when the child is not yet speaking, how do parents know when the child is no longer hungry? There is a large body of work that identifies verbal and non-verbal mimics and their interpretations to help understand the mechanisms governing appetite and satiation in children (Skinner et al. 1998; Gross et al. 2010; Hodges et al. 2013; Hetherington 2017; McNally et al. 2016; McNally et al. 2020). The following extracts from interviews show parents' difficulties in interpreting signs of hunger:

"If he wants more, he knows how to say 'more', so he says 'more' and even before he spoke, I had taught him the 'more' sign. [ ... ] There's baby sign language. It's like this [she gestures]". [Mother, high social position, boys 29 months and 4 years old].

"We saw that she saw us eating and we can see by her eyes, even though she's small, but we can see that ... she looks at the spoon and she goes ... [She imitates her daughter who follows the path of the spoon from the plate to her mouth with her eyes]. And if we sit her on our lap it's so cute because she sees the plate and she does the same thing [again she imitates the child following the path of the fork with her eyes]. So her eyes kind of say how scandalous ... " [Mother, middle-class social position, 11-month-old daughter].

"She's much more awake when she's hungry I think. She's more awake, more communicating than when she has something that's bothering her or she's a little bit sick... I rock her for five minutes and if after that she doesn't go back to sleep, I just make one [a bottle] for her. Then maybe it's an easy solution and the bottle knocks her out. But, uh..." [Father, high social position, daughter 7 months and son 4 years].

"It was clear, 'I don't want it', she would close her mouth or turn away, well it was clear. When she finishes everything, I tend to think I could have added more, anyway now she just says "more". And before, when she was smaller, I don't think she ever really finished her jars, but I would always do a little more than I had to, but actually she would stop. And she would usually stop by herself. And I never forced her to finish. As anxious as I am that she eats well, but... And I would tell the nanny, not to force her. In fact, I was in between, I mean to stimulate but not to force!" [Mother, high social position, one 31-month-old daughter]. 
Other issues are involved in the strategies parents and children put in place to manage this tension. Literature on the reward status of food, especially sugary food (Chiva 1979; Birch 1987; Cooke et al. 2011), is extensive as is the role of playful eating (Corbeau 2008). Other elements were observed here: serving vegetables before meat thus making more use of hunger mechanisms; acting on the temporalities of meals, particularly on their duration; reversing the structure of meals by starting with a fruit or dairy product and continuing with a protein dish; not serving water at the table. These illustrations show a distance from social, nutritional and educational norms as here.

"But here's the thing, the dessert is his goal I think. Because the nanny's got this weird way of doing things: she puts a tray in front of each of them and puts everything on it. So she puts the starter, the main course, the cut fruit, the cheese. So actually they eat in the order they want. [ ... ] But actually, at home I'm not in favor of it because I think that at school they won't get... Well, for me, the meal goes from the starter to the main course and dessert. It's true that at home I had a bit of trouble getting him to understand that he had to wait until he had finished the main course to have dessert". [Mother, middle-class social position, economic capital, 30-month-old boy].

"Yes, but he doesn't mind going back to salty after sweet. Yeah, the salty-sweet order, we're the ones who decided on this salty-sweet order but they don't care". [Mother, middle-class social position, economic capital, 30-month-old boy].

"When he comes home it is like "give me food, give me food!" so we often start with the dessert and by the time I finish he usually has an apple, a banana or a yogurt, then he eats the main course ... for me it doesn't matter if he eats the other way around, it's not a big deal". [Mother, middle-class social position, two boys aged 36 months and 6 years].

Moreover, the child is not just a receptor; they quickly learn to decode the strategies of their caregivers in order to adopt to them, just as they learn the social norms relating to ending meals with a dessert (Tibère and Dupuy 2021). For example, children who learn to save themselves for dessert in anticipation of sensory promises will tend to eat a smaller quantity of their protein dish. More common is the situation of going beyond one's hunger to please a caregiver who is being pushy and has forcing behaviors when it comes to food (Birch et al. 1980; Odgen et al. 2006; Gross et al. 2010). The following interview passage is very illustrative of a rigid control of the feeding behavior of the child:

"He drove me crazy on that dish. Because I wanted to do what I had been told: "you will not get any other food until you finish this". At 18 months old it's a bit hard, but at the same time this child drives me so crazy that I told him "ah okay, fine, you leave the table". And so I let him cry a little bit, he was crying because he wanted his caramel yogurt and there is no caramel yogurt if he doesn't eat that. Besides, if he had eaten it, he would have had plain yogurt. Yes, because there is a correlation: if he eats well, he gets a good yogurt, but there is no good yogurt if he does this. [Interviewer: It's pleasure yogurt only IF ... ] We don't like saying "good" yogurt, but hey, we're really into blackmail. Well it works well! He actually ate it a little bit, in the end. So I put him back and I told him curtly: "you want the yogurt, well you eat this!"; we had to try again several times by showing him. "If you want the yogurt, you eat this. He was crying and eventually he took the scoops. He took four. So we told him "thank you, that's a good job" and then we gave him his yogurt". [Mother, downgraded social position, two boys 18 months and $4 \frac{1}{2}$ years old].

The modalities of access to pleasure probably depend on the child's sex (Bournez et al. 2018), with gender norms participating silently to socialization and contributing to a stricter control of girls' eating practices, especially in the middle and upper social classes (Nicaise et al. 2019). This also occurs with older children (Dupuy 2013) as here:

"Lina I would say that she is more... well I find that she has her daddy's tastes, she likes sausage, cold cuts, cheese ... I'm not so much into cheese but Lina, she loves cheese. So I feel like she has more of her daddy's tastes, but I also try to influence her. [ ... ] [Talking 
about her partner] He's a big guy! (laughs) To give you an idea, when I met him he was $103 \mathrm{~kg}$, and now he must be over $120 \mathrm{~kg}$, I mean it's getting quite big. Well, he is tall, he is $1.93 m$, but still. Like I say sometimes, as Lina has Victor's taste, we have to be careful, so I do think about it. But to be honest, she has Victor's tastes, but I think that education is also important, and she is starting to learn, and for example, she likes fruit a lot, you see, for example, she often has fruit for dessert". [Mother, high social position, 4-year-old daughter and 11-month-old son].

"It's been 6 months now, he was going to the pantry. He's got a good idea of where that is. [... ] But we have to limit him. The other day, we went to the neighbors' and I thought that he was going to eat all the cakes and not leave any for anyone, so yes, you have to ... I told him, 'That's enough, leave some for the others,' but he doesn't care, as long as you don't put them out of reach, it's complicated ... well, it can be complicated". [Mother, high social position, 20-month-old boy].

As a consequence of the child's staturological growth, and as we have pointed out, parental management of the child's access to pleasure depends on the family's staturological history: parents project their own experience or that of their partner to discuss how their child relates to the pleasure of eating certain foods. In the same way, they sometimes project their own suffering in relation to their belittled body. Even if this issue appears later in the mechanisms of appetite and pleasure control in children (Dupuy 2013), what really matters here is the child's weight trajectory and its perception by the parents, as is expressed here:

"It is said that apparently children's weight determines adult weight. Say, if a child is very, very chubby as a child, there is a good chance that he will grow up to be so. Besides, we are the type of people who cannot eat anything without getting fat. Therefore, you have to be a little careful about what you eat, and I think that he will have this predisposition too". [Mother, intermediate social position, economic capital, 30-month-old boy].

"No, nothing in the morning, just water, it calls out. I know we can't afford to give him more, like I know he's at the top of the curve". [Mother, poor social position, 8-month-old boy].

It is also possible to distinguish certain processes that the caregivers have observed in the way the child learns to play with his hunger and satiety for his own pleasure or that of his family. This means that adults are not the only decision makers in children's eating practices, as children learn to decode and anticipate the reactions of their caregivers by shaping their own eating habits. These aspects underline the role of the interactions that take place from the earliest age between infants and the adults who feed them, thus contributing to the construction not only of food repertoire but also, in part, of personalities and individual and social identities (Chiva 1979). This is tempered by the adoption of an adult- or child-centered stance on needs and their expression, which in turn is often dependent on a number of determinants and normative processes about the role to be granted to children in their socialization. In this sense and to keep things simple, it is more accurate to speak of ideal-typical views.

In the first view, the adult considers himself competent to understand the needs expressed by the child. The adult's intervention responds to the child's expressed needs within the framework set by the adult alone. In this mode of interaction, the adult may encourage the child to eat more, deny access to more food, or put food out of reach or out of sight. This mother expresses the difficulties and the anguish of feeding a child who does not eat which explains the incentives to eat:

"That's the problem, Agathe never asks for food, never makes you feel the urge to eat, so ... [ ... ] Yes, but then as she loses focus very quickly, we often put her at the table with us, so she starts to eat and then she starts to lose interest or to look to the right or to the left, and often we help her so she can eat a little more fully otherwise it will pass, she'll forget and then she'll be grumpy. So she'll never say she's hungry, if we ask her she'll say 'no' but in fact she is, so we help her". [Mother, downgraded social position, 18-month-old daughter] 
In the second view, the adult intervenes only to respond to the needs expressed by the child, who is considered to be competent to correctly express his or her hunger or satiety. The adult responds to the child's requests but does not insist, refuse or encourage them. This analysis thus extends reflections on feeding styles (Hughes et al. 2016) as well as reflections on feeding temperaments in children (Farrow and Blissett 2006). Recent experimental work shows that at 11 months of age, if the pace of spooning is slower when spoonfuls are large (reflecting more responsive feeding), infants have better energy adjustment abilities. In other words, they are better able to cut back on the amounts they eat at mealtime after eating a high-energy first food (Brugaillères et al. 2019).

Furthermore, these adult- or child-centered views are linked to normative and imaginary productions that people have about childhood, i.e., the competent child, the responsible child, the victimized or vulnerable child (Hamelin Brabant and Turmel 2012), all of which are deployed differently depending on social environments. Eventually, these dimensions may evolve as children advance in age and in autonomy as what is expressed by these parents.

"But for example, when it is 6 o'clock in the morning, she is not going to say "I'm hungry"? Ah no, she has no idea". [Mother, low social position, 17-month-old daughter].

"In terms of quantities, he manages himself, and so we don't have to give him anything, so it's nice, we're focused on our plate, well we check where he is, etc., but we don't have to hand him the fork, the spoon, etc. Each one manages his own plate". [Mother, low social position, 32-month-old boy].

"Yes, she says it, but hunger I think is the thing she knows how to express the least [... ] She never says "I'm hungry", she says "ham", I think hunger is the thing she expresses the least". [Mother, middle-class social position, 30-month-old girl].

"I know that he is aware of his needs, his hunger and everything. Last night he said "well I didn't eat much daddy, I'm hungry" so he took another slice of pizza. So, he knows when he is hungry, how to deal with it, and he expresses it well. So it's pretty easy in that respect". [Mother, low social position, 32-month-old boy].

"Because the pediatrician probably told me that it was at that age that it had to be done. Because at some point they sit up, they grow up and eating is good, integrating food as they go along, developing taste, I figure it's extraordinary rather than drinking milk forever, ... and then for them, this discovery, the face they make when there is this or that taste in their mouth, the look they make when they refuse such food because for them it is unthinkable to eat that ... Well, anyway, it also shows that they are human beings in their own right and that they develop their own tastes. So there you go, I really followed it up, as closely as possible". [Mother, middle-class social position, two boys aged 36 months and 6 years].

For this same view, the lexical analysis indicates a parental discourse that values the "natural" rhythms of children and their ability to express their needs. Perceptions are then based on trust in the signals given and, depending on the social environment, on the image of the "healthy" child or on listening to what "the stomach can handle".

"When they request food, I give them food and when they don't need to eat, I just don't insist. [ ...] You trust them. We have children who are very healthy when it comes to food, so we're lucky. It's an opportunity to trust them". [Father, high social position, daughter 7 months and son 4 years, $p<0.0001]$.

"He says "Mommy, I want an ice cream", so he chooses an ice cream he likes, he doesn't finish it, so I tell him "well Victor, you chose an ice cream that you didn't finish ..." but I don't see the point of forcing a child to finish something, I figure that naturally he's not hungry anymore. I don't know ... he ate a piece of his ice cream, he ate $\frac{3}{4}$ of it, I think it was a little big for him, I don't want to be a food Hitler. So I think to myself "it is not just a whim to want food, but at some point I think that he is 3 years old, that 
he has a stomach that can handle so much ... " because when it comes to my children, I often work as though it were happening to me: I want dessert, but I am not hungry anymore, I am not gonna gorge myself on dessert just to finish my plate. So no ... when I see friends doing that, it hurts my heart so much that it's unthinkable, if you've opened a bottle of wine, I'm not gonna force you to finish the whole bottle. No but it doesn't apply to everything. He wanted dessert and then he didn't want it anymore, so that means he's had enough to eat". [Mother, middle-class social position, two boys aged 36 months and 6 years].

\subsubsection{The Dynamics of Daily Food Routines}

The practices of daily meal preparation to feed a child consist of a sequence of operations, ranging from procurement to the management of leftover storage. These operations are sequenced through routine practices (Gottlieb 2000; Dubuisson-Quellier 2006). The coordination into action sequences of such practices constitutes a cognitive economy (Piette 2013) consisting of adopting mental shortcuts to purchase, produce, consume, and manage leftovers (Poulain 2002, 2017). In previous research, we have shown that "food work" and the associated routines are inserted into the constraints of families (Dupuy and Rochedy 2018) as well as those of professionals (Dupuy et al. 2018b). This has implications on the food produced for children, in particular the presence of a certain monotony in terms of the repertoire of foods given and textures offered (Dupuy et al. 2018a). No longer weighing, no longer measuring out quantities, guessing meal portions or even serving them by the "ladle" means that daily preparation practices have been routinized with the experience acquired through the recurrence of situations as here.

"I followed, I mean I figured out the quantities. For the ham, for example, I would give half a slice. Yes, it did seem very, very precise, but for example I never used the weighing scales, I used the eye but I think I would put less than more. Then, from the age of one, it's easier because there's more quantity. Yes, since in 5 months the quantities are multiplied by 5". [Mother, middle-class social position, 21-month-old boy].

It has been shown that the least educated social classes have fixed practices while families with a middle or high level of education have more varied practices (Southerton 2006; Diasio and Julien 2018). Discussing the dynamics of daily preparation practices amounts to better accounting for the effect of contexts on "food work" routine practices and their impact on quantity dosages and portion sizes served to children. Diversification in very young children involves expanding the food repertoire in terms of content, quantity and texture. During this process, which may vary according to the situation, location and socialization context, periods of stabilization and transition can be distinguished, which, as generated and motivated by parents, also affect their workload as food providers. This mother explains the seasonal adaptations that she implements:

"I try as much as possible, knowing that it's been a few weeks since I started to rebalance my diet, because we are getting close to summer and so in the evening I tend to go for raw salads rather than the heavy dishes. So in the end, pasta ... well, we had some one evening, two days ago, but other than that, I hadn't made pasta or rice or wheat for weeks. I usually save that for lunch". [Mother, middle-class social position, economic capital, 30-month-old boy].

When stabilization reflects a habit-building effort, it reinforces routinization and has a beneficial effect on parents, as it allows them to mentally relax into the "food work." However, the fact that less cognitive energy may be spent leads to nutritional errors such as when the quantity is sufficient yet the caloric density of the preparation is not, much like what this mother mentions on several occasions in the two interviews:

Interview 1: "But I actually thought I was weighing, but actually I wasn't weighing, I was looking at the dose. Because that evening when I put my puree on, I said to myself, 'Damn, it's compact'. Sometimes I add water before mixing, but in this case I didn't add any, I thought there was enough. But then he must have taken maybe $300 \mathrm{~g}$ of puree, I'm 
not sure. [ . . . B But in fact I hadn't measured it and I think there was more [ . . ] But actually it's a bit stupid, because actually you have to weigh it. Because it depends if your puree is light... it's not the quantity that will count in fact it's the weight. And that's where I fooled myself because my puree was very compact, and I think that this portion weighed much more than an industrial jar, which in fact contains a lot of water and everything". [Mother, high social position, a 12-month-old boy and a 4-year-old girl].

Interview 2: "And so I no longer measure. It used to do my head in, but not anymore. I pretty much get the quantities now. Before, when he was little, I used to fill the jars full, you know ... Well, now it's pieces, it doesn't mean the same and now I can tell it's a small bowl and if he doesn't finish, he doesn't finish, it's up to him". [Mother, high social position, a 12-month-old boy and a 4-year-old girl].

This was particularly observed in the choice of texture and in the number of ingredients comprising the meal, but it is also the case with the quantity served to the children. Since "food work" is tied to temporal, material and organizational constraints, and since it operates within a search for cognitive economy, dietary changes may be deferred, consciously or unconsciously. Indeed, putting an end to a routine requires reflexivity and renewed decision making, such as increasing the quantity served or the number of food intakes, modifying and diversifying the number of ingredients and textures offered. Routinization ultimately reflects what works best, what has been successful and/or what the child prefers, allowing the caregivers to feed without hindrance and with minimal effort. Change, on the other hand, generates potential mental and physical burdens resulting in fatigue, without necessarily guaranteeing success in terms of actual consumption. This food management, a kind of daily micro-management, affects the quality as well as the quantity offered to the children.

Even when parents are forced to innovate, as a result of changes in children's diets and because they respond, to a greater or lesser extent, to dietary standards and injunctions, and also as a result of the interactions, situations, and contexts in which socialization occurs, the integration of the child into the family's dietary repertoire is then an opportunity to ensure family socialization, while also alleviating the physical and mental burden on the caregivers. Learnings are carried out in a social environment marked by parental consumptions, which are themselves socially and culturally determined (Fielding-Singh 2017). This integration dimension becomes even more obvious when the child is not the first born sibling. Parents report that for the second child, diversification and integration of the child into the family food repertoire occurs more quickly (Yuan et al. 2016; Bournez et al. 2018, 2019; Dupuy et al. 2018a). Older siblings are models of integration that the child looks to for socialization. The alleviation of physical and cognitive burdens that results from this daily socialization, through serving the same ingredients as for the rest of the family, has an impact on shopping, supplies, preparation, and budget, while food is specifically tailored to meet needs that are more or less perceived and expressed in terms of tastes, nutritional composition, quantities, and portion sizes. Sometimes the quantities are identical between siblings (as, indeed, for groups of children cared for by home-based childminders in our qualitative survey).

Moreover, as previously identified (Lalanne and Tibère 2008; Tibère et al. 2018), reported routines - that is, what is presented by parents as usual practices-may be distinct from what is observed and analyzed during the survey situation, i.e., the actual routines. This research shows the importance of contextual changes, or contingencies, in terms of the social, temporal or spatial environment of food intake. The impact of social contexts can also come into focus in understanding the role of derogations on what is given and how much is given in connection with various educational tensions (Lalanne and Tibère 2008; Dupuy 2013; Dupuy 2017b). These are not epiphenomena in the course of socialization. Their recurrence affects the quantities offered and ultimately consumed. In this sense, contextual derogations correspond to determinants of children's appetite and satiety, and, more broadly, to the regulation of food intake in children, and reveal forms of normative distancing in situ. The following excerpt is an exchange with a concerned 
mother during the second interview, which comes along with the viewing of photos taken of eating situations. It shows the momentary difficulties encountered by this mother with her 18-month-old son, which repeatedly resulted in milk intake and a refusal to consume anything other than a bottle.

"So this one is a serious regression! He was always taking Babybio, except that it is for 6 months old, he is 18 months old; we decided that we would evolve, we would buy Blédichef, but Blédichef has pieces, so he doesn't eat them, he just turns his head. So we ended up giving him a bottle. So from time to time, when we have some, we serve him a Babybio, he takes it ok, but now for example at lunch he had a bottle. Because yeah, I brought out the Babybio from last night that he didn't eat, and he didn't want it ... But since I'm so tired, "well, have a bottle". [The mother goes to change her son's diaper] And the craziest thing is that Arnaud doesn't eat anything, but you wouldn't believe how many poops a day he makes... But poops of what? Right now his poop is not brown, but rather beige, like milk poop. I'm 18 months old, I make milk poop". [Mother, downgraded social position, a 18-month-old boy].

Picture 6: Arnaud, 18 months: Dinner "failure", after failed attempt of a jar, proposal quiche/cucumber like the rest of the family, but without success. Did not eat anything, bottle offered and ok.

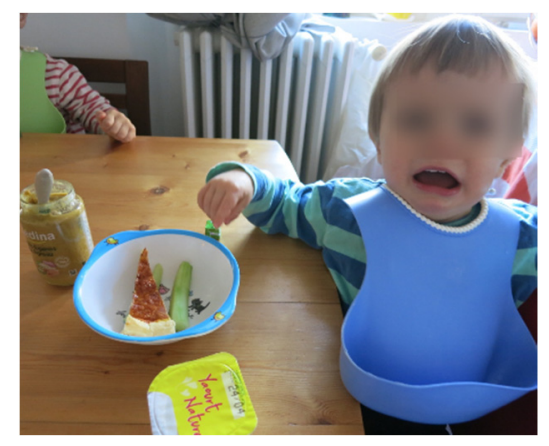

Pictures 7 and 8: Arnaud, 18 months: Evening meal: Carrot puree, did not eat it. Tried a chunk of cooked carrot without success. Ended up with a bottle of milk.

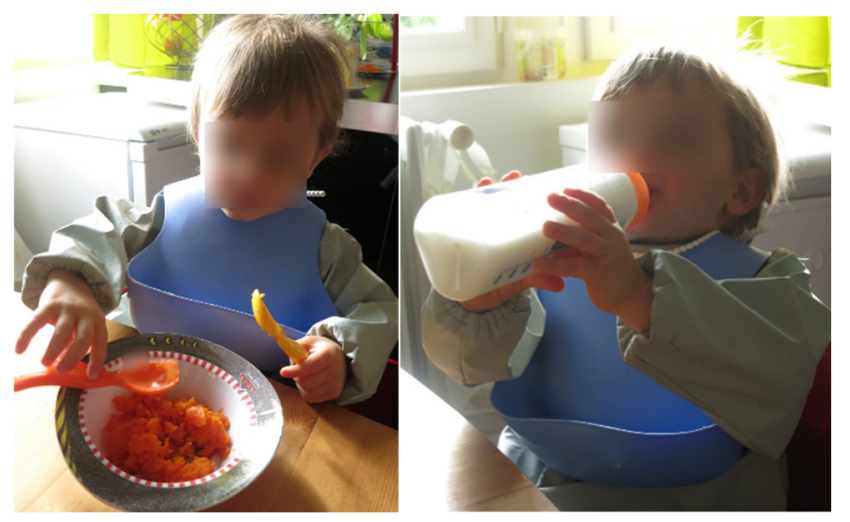

\section{Discussion}

Although the interviews are partly regulated by the tools and protocols that support them, they remain social improvisations insofar as the interviewers do not control the entirety of the interactions and the content expressed, unlike quantitative protocols which are based on closed questions. It is therefore interesting to note the extent to which the child's appetite and satiation seem to be regulated by social, nutritional and educational norms; these norms can be objectified by the statistical analysis produced here. These lexical universes stem from social and normative contexts that play a significant role in the socialization of children and greatly condition the type, amount and timing of food 
intake by setting food repertoires, in particular the type and alternation of food intake (solid/liquid) as well as the structure of meals (starter and/or main course and/or dessert, drinks and snacks, etc.), food rhythms which include synchrony, social manners and forms of consumption, in particular commensality.

Among parents, mostly mothers, the results confirm the importance of nutritional and child care norms, but also the status of food models in their social dimensions, including, in particular, an ambivalent relationship to sweet foods, the importance of salty foods at meals, the learning of food rhythms, and the rules of commensality on which parents rely to determine appetite and satiation. The proportions associated with these classes reflect their importance in the whole corpus, allowing them to be ranked in a hierarchy. Class 5, which relates to the social frameworks of commensality, i.e., the learning of table manners and conviviality, is the most represented, followed by Class 1, which relates to the relationship with medical norms, insofar as infant nutrition is strongly regulated by medical, early childhood and family authorities. In France, the social norms that are expressed in terms of table manners and the medical norms regarding infant nutrition are the most socially marked determinants; they are found to be more or less articulated according to the parents. Additionally, the significant interest of parents from wealthy social backgrounds for medical norms is established as has been identified elsewhere (Gojard 2000; Régnier and Masullo 2009; Dhuot 2018).

These elements concur in considering the importance of social and medical norms in the perceptions of adults concerning these two aspects, and invite us to identify how these norms are incorporated by young children, transforming their hunger into appetite, and their satiety into satiation. There are three dynamics that characterize the way in which the social system takes charge of certain perceived signals: the one that is focused on the child's growth and the evolution of his physiological, social and emotional needs; the one that is focused on the signals associated with satiation, in line with food pleasure and desire; and finally, the one related to practical and daily preparation practices, where routines are established, particularly in the management of textures and portions, thus establishing normative compliance with or distancing from the norms in situ.

At first glance, these results seem to reflect a top-down education-from adults to children-regarding socialization and, in particular, hunger and satiety. Beyond physiological sensations, the issue of social integration of children is prevailing, with a focus on preschool admission and school meal attendance and also a gendered relationship to food. This reveals how hunger and satiation are, respectively, transmitted into appetite and satiation through the inculcation of normative frameworks and the more or less strong respect of educational principles. Social frameworks and normative goals are combined in the recommendations of the French public authorities, such as the examples of menus that are adapted according to the age of the child in the guide "L'alimentation pendant la petite enfance (de la naissance à 3 ans)" of the Programme National Nutrition Santé, available at the time of the qualitative survey on the website Manger.bouger.fr. This guide sets out the structure of a day and food intake. This jumble of normative registers can be traced, to a greater or lesser extent, in the parents' speeches revealed by this investigation. It changes according to the parents' social background, forming a relationship of attachment, distancing or even rejection to food and nutritional norms, as has been shown in other studies (Gojard 2000; Régnier and Masullo 2009; Dhuot 2018). It also changes according to experience, like the differences that can be found in families with one or more children, or the distinctions between parents and professionals in the modalities of educational delegation (Dupuy et al. 2018b). This aspect echoes a salient finding from Séverine Gojard's survey relating to the level of experience caring for young children and autonomy in relation to prescriptions (Gojard 2010). However, what varies less is this relationship to the normative content on which parents rely to express themselves, both because parental practices, especially maternal ones, are framed by a "moral magisterium" (Garcia 2011) that is prevalent with the rise of child obesity and associated pathologies, but also because 
these norms correspond to models of conduct that are widely followed in society or in certain social groups and that are considered appropriate (Poulain 2002, 2017).

As scientific findings evolve, dietary and educational standards on feeding fluctuate to describe what constitutes "good" behavior to maintain young children in a state of good health and well-being. The norm of "responsive feeding", which is more inclined to a less vertical relationship between adults and children, by making the caregivers more aware of the child's needs, is giving rise to new recommendations and prescriptions. These are disseminated by the medical community, public authorities and their agents. The effect can be to question the importance of the vertical relationship or even to accompany it with new recommendations, which are meant to correct it. However, this often happens without any regard for the importance of the contexts in which the norms that parents rely on to varying degrees of intensity are produced, and their sociohistorical anchorage. The discrepancy between medical prescriptions and daily socialization should not result in addressing, from the angle of lack of parental and often maternal nutritional skills, situations that public policies have trouble grasping in their complexity and plurality as well as in their social, cultural and historical depth.

\section{Limitations of This Study}

The dynamics at work in children's eating were not systematically and directly observed in the research protocol. However, their observation would probably allow researchers to prioritize these determinants according to the child's gender, biological and social age, lifestyle and associated constraints.

However, the iterative method used and supported by the use of photo elicitation reduces the effect of declarative and social desirability by revealing discrepancies and deviations between norms and practices, on the one hand, and declared routines and actual routines, on the other, as illustrated by the following situation:

"Now it's true that, compared to what we said last time, I think I actually tend to give him a lot of food in terms of quantity. Because afterwards I discussed it with my partner and he did say to me "you've never seen the quantities they give at the nursery, but it's really small portions, and compared to what you give him, it's just enormous", well I mean it's more. [... ] Because basically his baby plate shouldn't be full, and actually sometimes I do fill it up. And I don't know where that comes from ..."

[Mother, high social position, two boys aged 5 and 29 months].

Additionally, this multistep investigation process encourages the emergence of a reflexivity made possible by the identification, during the interaction, of situations of derogation linked to the numerous contexts that intervene in the socialization.

This study mainly concerns children with what could be considered in pediatrics as "typical" development. Despite the fact that no exclusion criteria were set related to pathologies or early events which could have a potential consequence on the organization of child feeding (such as gastroesophageal reflux disease, cow's milk protein allergy, nasogastric intubation, congenital abnormalities of the digestive tract, and extreme premature birth), it is obvious according to parent responses that children within this sample were not presenting any of these conditions. The present results can only be interpreted for this population. For children with specific conditions, the application of more normative feeding practices may actually be beneficial for child development (e.g., food restriction in the case of food allergy; nutritional enrichment in the case of extreme premature birth to ensure growth catch up).

\section{Conclusions}

This article provides an overview of the levels and modalities involved in the perception of hunger, appetite, satiation and satiety in young children by the adults who feed them. It highlights the influence of nutritional, social and educational norms on which parents in France rely variably according to their social backgrounds and parental experience in order to supervise the practices of young children. These levels of perception are also part of the 
day-to-day "food work", which, through social practices, activities and interactions around food, inhibits or reinforces the effect of normative frameworks and educational models and thus socializes children and determines how much, when, what and how to eat in the household and other contexts. Finally, this article clarifies the conditions and limits of a top-down education - from adults to children — on hunger and satiety. To that end, this article relates this process to the fluctuating recommendations of "good" behavior likely to maintain young children in a state of good health and well-being and which are in keeping with scientific discoveries. In terms of applications, this study calls for better consideration of these aspects in nutritional recommendations so as not to increase the moralization of behaviors considered non-compliant. The redefinition of food education standards, on which nutritional policies for parents are based, must be established in accordance with the standards on which households rely. The risk is otherwise of saturating the already numerous normative mechanisms in France by which parents find their way, which would be counterproductive. The risk is also to participate in reinforcing the effects of "parental determinism" (Furedi 2002) by reinforcing the idea that parents are bad educators.

On the epistemological level, this work brings to light a number of connections between the psycho-sensorial, psycho-cognitive and socioanthropological dimensions of food, as well as food-related education. It sheds additional light on the ways in which socialization unfolds in the interactions between the child and those around him, but also in the more or less strong and conscious movements back and forth between dietary and educational social norms, physiological, psycho-sensory and psychomotor signals emitted by the child and decoded by adults, and finally in the interactions with the daily environment, concrete practices and routines that organize socialization. In this respect, work on the food socialization of young children can contribute to a deeper understanding of the processes by which the biological, the ecological, the psychological and the sociological are shaped together.

Author Contributions: A.D. designed the protocol, conducted the field qualitative survey, analyzed and drafted the results, and wrote this article. S.N. secured the funding and coordinated the ANR research. S.G. participated in the data collection. S.N., C.S. and L.T. participated in writing this article. All authors read and approved the final manuscript and consent to publication in this journal.

Funding: This research is supported by the Agence Nationale de la Recherche in France. ANR-15CE21-0014, PUNCH, Promoting and Understanding healthy food choices in Children. The authors wish to thank the parents, home-based child care providers, and children who participated in this research. We also thank Margaux Huille and Audrey Bardet, ISTHIA trainees for this study, Joël Courant and Pierre Ratinaud for computer science support and Christelle Abraham for the financial management of this research. Thank also the ISTHIA. We would like to thank Marie Laurent-Badin Vilain for translating this article into English. Finally, we thank the reviewers from Social Sciences, JeanPierre Poulain, guest editor, and Marina Crina, assistant editor, who contributed to the improvement of our article. The study was conducted according to the guidelines of the Declaration of Helsinki, and approved by Ethics Committee of Université Fédérale de Toulouse IRB \# 1 (retrospective ethical approval No: IRB00011835-2019-09-24-180, 9/24/2019).

Informed Consent Statement: Informed consent was obtained from all subjects involved in the study.

Conflicts of Interest: The authors declare no conflict of interest. The founding sponsors (ANR) had no role in the design of the study; in the collection, analyses, or interpretation of data; in the writing of the manuscript; and in the decision to publish the results. 


\section{Appendix A}

Table A1. Interview guide.

\begin{tabular}{|c|c|}
\hline \multicolumn{2}{|r|}{ Parents } \\
\hline Topics & Subtopics \\
\hline $\begin{array}{l}\text { Information about the respondent } \\
\text { and his/her family }\end{array}$ & Family situation and organization \\
\hline \multirow[t]{3}{*}{ Food at home } & Provisioning, including focus on child \\
\hline & Meal preparation, including a focus on the child \\
\hline & $\begin{array}{l}\text { Preparation of child's meals: help, influences, } \\
\text { recommendations and consideration of needs and wishes } \\
\text { expressed by the child }\end{array}$ \\
\hline Child's relationship to food & $\begin{array}{l}\text { How does the child express that he is hungry? That he is } \\
\text { satiated? How to describe the child's appetite }\end{array}$ \\
\hline $\begin{array}{l}\text { Child's nutrition and child care } \\
\text { arrangements }\end{array}$ & Educational delegation and food delegation \\
\hline \multirow[t]{2}{*}{$\begin{array}{l}\text { Dietary adjustments according to } \\
\text { the child's advancement in age }\end{array}$} & Evolution of the diet \\
\hline & Relationship to weight in childhood \\
\hline Before diversification & Breast-feeding methods and weaning \\
\hline \multirow[t]{2}{*}{ Educational styles and eating styles } & Transmission issues and life experience \\
\hline & Differences between children in multiparous families \\
\hline Photo protocol & $\begin{array}{l}\text { Meals and leftovers contextualized according to specific } \\
\text { situations (e.g., when the child is tired, when you are tired, } \\
\text { the child liked, the child did not like) }\end{array}$ \\
\hline \multirow[t]{3}{*}{ Second interview } & $\begin{array}{l}\text { Link with the previous interview: changes, clarifications } \\
\text { to be made according to the respondent }\end{array}$ \\
\hline & $\begin{array}{l}\text { Forgotten questions, poorly conducted follow-up, } \\
\text { paradoxes identified by the interviewer }\end{array}$ \\
\hline & $\begin{array}{l}\text { Description about the photos taken (contexts, reasons for } \\
\text { selection, quantities served and leftovers left by the child) }\end{array}$ \\
\hline
\end{tabular}

\section{Appendix B. Details of the Lexicometric Analyses Carried Out on the Corpus}

To constitute each corpus, preparation is necessary, consisting of division into units: here, each parent constitutes an initial context unit to which certain characteristics are associated. These additional variables are introduced to compare their distribution in the classes of significant statements. These classes are generated following a hierarchical top-down classification that combines vocabulary and statements similar to each other and distinct from those of other classes. For each corpus, a hierarchical top-down classification is conducted to identify, using an iterative procedure, the classes of significant statements and to highlight the general themes of the corpus as well as the internal organization of the discourse. In addition to the frequency of words within classes, the analysis enables us to understand the variety of discourse, the meaning of words and their relationships.

The results (selection) are represented by dendrograms and tables (in Appendices C and D, below), allowing identifying the segmentation of the corpus into classes. Each class contains a certain number of words, which are sorted by their strength of association with the class. The words appearing at the top of the list of the class words (or in large characters in the dendrograms with associated words) are the most representative words of the class according to the value and the strength of their chi2: the higher the chi2, the more likely the hypothesis of dependence between the word and the class. When a word is found in several classes, its position in the word list means that it is characteristic of that particular 
class compared to others. Finally, the lower the $\mathrm{p}$ value, the smaller the margin of error of the dependency test.

Concerning the corpus (see Section 3.2), the analyses are carried out on a corpus of 28 texts, corresponding to the 28 households surveyed, comprising 430,926 occurrences, 6874 lemmas and 2594 hapaxes $(0.60 \%$ of the occurrences- $38 \%$ of the forms). The average number of occurrences per text is 15,390 . As a result, 14 initial context units have been introduced to differentiate each parent. In the software, these are starred words to characterize the number of the parent in order to differentiate him/her: the status of the respondent (mother or father), the number of children, the social position of the household based on the level of diploma and resources of the parents, the level of diploma and resources of the household, the sex of the child, the medical follow-up of the child, the age of the child, the relationship to nutritional recommendations declared by the parent based on the question about the sources of advice for breastfeeding, weaning and diversification, duration of breastfeeding, age of diversification, season of diversification, type of diversification (salty or sweet) and type of food served for diversification (homemade, industrial jar, or combination).

The dynamic analysis is then processed on the basis of the corpus of 20 parents interviewed on two occasions (see Section 3.3.1). In this analysis, the lexical universes are compared within a period of 44 days on average $(\sigma=28.6)$. The analyses cover a corpus of 40 texts. For the corpus relating to the first interview, it includes 245,527 occurrences, 5330 lemmas and 2057 hapaxes ( $0.84 \%$ of occurrences $-39 \%$ of forms). The average number of occurrences per text is 12,276. For the corpus relating to the second interview, it includes 121,928 occurrences, 3861 lemmas and 1617 hapax $(1.33 \%$ of the occurrences- $42 \%$ of the forms) and the average of the occurrences per text is 6096 .

\section{Appendix C}

Table A2. Classes, ratio, Chi2 and p for parents: first associated words.

\begin{tabular}{cccc}
\hline Words & Subtotal to Total Ratio & Chi2 & $p$ \\
\hline $\begin{array}{c}\text { Class } 1 \\
\text { Relating to the Medical }\end{array}$ & $\begin{array}{c}\text { 2507/11,387 }=22.02 \% \text { of } \\
\text { Classified Segments }\end{array}$ & & \\
\hline Weight & $98 / 104=94.23 \%$ & 318.8 & $p<0.0001$ \\
\hline Height & $40 / 50=80 \%$ & 98.34 & $p<0.0001$ \\
\hline Concern & $58 / 78=74.36 \%$ & 125.33 & $p<0.0001$ \\
\hline Problem & $86 / 162=53.09 \%$ & 92.4 & $p<0.0001$ \\
\hline Difficulties & $67 / 123=54.47 \%$ & 76.29 & $p<0.0001$ \\
\hline Reflux & $34 / 37=91.89 \%$ & 105.56 & $p<0.0001$ \\
\hline Worry & $41 / 78=52.56 \%$ & 42.69 & $p<0.0001$ \\
\hline Girls & $49 / 76=64.47 \%$ & 80.33 & $p<0.0001$ \\
\hline Health & $43 / 47=91.49 \%$ & 132.67 & $p<0.0001$ \\
\hline Curve & $66 / 66=100 \%$ & 235.14 & $p<0.0001$ \\
\hline Pediatrician & $125 / 168=74.4 \%$ & 272.58 & $p<0.0001$ \\
\hline Doctor & $96 / 116=82.76 \%$ & 251.85 & $p<0.0001$ \\
\hline Booklet (Health) & $19 / 19=100 \%$ & 67.41 & $p<0.0001$ \\
\hline General practitioner & $19 / 19=100 \%$ & 67.41 & $p<0.0001$ \\
\hline
\end{tabular}


Table A2. Cont.

\begin{tabular}{|c|c|c|c|}
\hline Words & Subtotal to Total Ratio & Chi2 & $p$ \\
\hline Growth & $21 / 26=80.77 \%$ & 52.39 & $p<0.0001$ \\
\hline Allergy & $22 / 26=84.62 \%$ & 59.48 & $p<0.0001$ \\
\hline Weighing & $24 / 34=70.59 \%$ & 46.86 & $p<0.0001$ \\
\hline Vomiting & $29 / 44=65.91 \%$ & 49.56 & $p<0.0001$ \\
\hline Body & $14 / 16=87.5 \%$ & 40.02 & $p<0.0001$ \\
\hline Sick & $54 / 116=46.55 \%$ & 41.09 & $p<0.0001$ \\
\hline $\begin{array}{l}\text { Parents with high education and } \\
\text { income }\end{array}$ & $201 / 615=32.68 \%$ & 43.08 & $p<0.0001$ \\
\hline $\begin{array}{l}\text { Children followed by a } \\
\text { pediatrician and a general } \\
\text { practitioner }\end{array}$ & $869 / 3385=25.67 \%$ & 37.5 & $p<0.0001$ \\
\hline $\begin{array}{l}\text { Class } 2 \\
\text { Relationship to the sweet food } \\
\text { repertoire }\end{array}$ & $\begin{array}{l}2018 / 11,387=17.72 \% \text { of } \\
\text { classified segments }\end{array}$ & & \\
\hline Chocolate & $136 / 179=75.98 \%$ & 423.27 & $p<0.0001$ \\
\hline Cakes & $129 / 231=55.84 \%$ & 235.0 & $p<0.0001$ \\
\hline Sweet & $136 / 191=71.2 \%$ & 381.07 & $p<0.0001$ \\
\hline Sugar & $103 / 124=83.06 \%$ & 367.09 & $p<0.0001$ \\
\hline $\begin{array}{l}\text { Parents with the lowest levels of } \\
\text { education and income }\end{array}$ & $98 / 450=21.78 \%$ & 5.29 & $p=0.02150$ \\
\hline Fruits & $238 / 334=71.26 \%$ & 676.34 & $p<0.0001$ \\
\hline Compotes & $230 / 355=64.79 \%$ & 556.69 & $p<0.0001$ \\
\hline Organic & $130 / 155=83.87 \%$ & 471.56 & $p<0.0001$ \\
\hline Markets & $94 / 150=62.67 \%$ & 210.58 & $p<0.0001$ \\
\hline Dairy products & $147 / 480=30.63 \%$ & 57.22 & $p<0.0001$ \\
\hline Yogurts & $270 / 369=73.17 \%$ & 804.12 & $p<0.0001$ \\
\hline Cheese & $114 / 273=41.76 \%$ & 110.83 & $p<0.0001$ \\
\hline $\begin{array}{l}\text { Parents with high levels of } \\
\text { education and income }\end{array}$ & $137 / 615=22.28 \%$ & 9.25 & $p=0.00235$ \\
\hline High social position & $795 / 4206=18.9 \%$ & 6.36 & $p=0.01164$ \\
\hline $\begin{array}{c}\text { Class } 3 \\
\text { Relationship to the salty } \\
\text { food repertoire }\end{array}$ & $\begin{array}{l}2415 / 11,387=21.21 \% \text { of } \\
\text { classified segments }\end{array}$ & & \\
\hline Vegetables & $328 / 473=69.34 \%$ & 684.29 & $p<0.0001$ \\
\hline Carrot & $202 / 226=89.38 \%$ & 641.27 & $p<0.0001$ \\
\hline Tomato & $113 / 121=93.39 \%$ & 381.3 & $p<0.0001$ \\
\hline Zucchini & $97 / 105=92.38 \%$ & 321.26 & $p<0.0001$ \\
\hline Pasta & $221 / 310=71.29 \%$ & 478.33 & $p<0.0001$ \\
\hline Rice & $106 / 147=72.11 \%$ & 230.9 & $p<0.0001$ \\
\hline Meat & $248 / 316=78.48 \%$ & 637.99 & $p<0.0001$ \\
\hline Ham & $118 / 132=89.39 \%$ & 371.56 & $p<0.0001$ \\
\hline
\end{tabular}


Table A2. Cont.

\begin{tabular}{|c|c|c|c|}
\hline Words & Subtotal to Total Ratio & Chi2 & $p$ \\
\hline Parents compliant with the norms & $1470 / 6274=23.43 \%$ & 41.27 & $p<0.0001$ \\
\hline Parents with a daughter & $1117 / 4810=23.22 \%$ & 20.22 & $p<0.0001$ \\
\hline $\begin{array}{l}\text { Parents with a high level } \\
\text { of education }\end{array}$ & $327 / 1347=24.28 \%$ & 8.6 & $p=0.00335$ \\
\hline $\begin{array}{l}\text { Parents with low income but } \\
\text { high education }\end{array}$ & $419 / 1769=23.69 \%$ & 7.69 & $p=0.00554$ \\
\hline $\begin{array}{c}\text { Class } 4 \\
\text { Temporal framework of food } \\
\text { socialization }\end{array}$ & $\begin{array}{c}1659 / 11,387=14.57 \% \text { of } \\
\text { classified segments }\end{array}$ & & \\
\hline Morning & $239 / 378=63.23 \%$ & 743.73 & $p<0.0001$ \\
\hline Evening & $308 / 668=46.11 \%$ & 567.1 & $p<0.0001$ \\
\hline Night & $128 / 167=76.65 \%$ & 524.75 & $p<0.0001$ \\
\hline Noon & $207 / 384=53.91 \%$ & 494.06 & $p<0.0001$ \\
\hline Waking up & $99 / 113=87.61 \%$ & 489.21 & $p<0.0001$ \\
\hline Time & $166 / 306=54.25 \%$ & 397.76 & $p<0.0001$ \\
\hline $\begin{array}{l}\text { Parents reporting medical } \\
\text { follow-up of their child by } \\
\text { a pediatrician }\end{array}$ & $1112 / 6687=16.63 \%$ & 55.24 & $p<0.0001$ \\
\hline $\begin{array}{l}\text { Parents of a middle-class social } \\
\text { position }\end{array}$ & $424 / 2544=16.67 \%$ & 11.58 & $p=0.00066$ \\
\hline $\begin{array}{l}\text { Parents with a moderate level of } \\
\text { education and income }\end{array}$ & $384 / 2294=16.74 \%$ & 11.58 & $p=0.00097$ \\
\hline $\begin{array}{l}\text { Parents with a low level of } \\
\text { education and income }\end{array}$ & $222 / 1291=17.2 \%$ & 8.07 & $p=0.00449$ \\
\hline Primiparous & $1073 / 7002=15.32 \%$ & 8.33 & $p=0.00390$ \\
\hline $\begin{array}{c}\text { Class } 5 \\
\text { Social framework of food } \\
\text { socialization }\end{array}$ & $\begin{array}{l}2788 / 11,387=24.48 \% \text { of } \\
\text { classified segments }\end{array}$ & & \\
\hline Table & $241 / 321=75.08 \%$ & 457.3 & $p<0.0001$ \\
\hline Play & $165 / 247=66.8 \%$ & 244.53 & $p<0.0001$ \\
\hline Hunger & $237 / 429=55.24 \%$ & 228.14 & $p<0.0001$ \\
\hline Meals & $244 / 632=38.61 \%$ & 72.19 & $p<0.0001$ \\
\hline Parents with low social position & $226 / 748=30.21 \%$ & 14.22 & $p=0.00016$ \\
\hline $\begin{array}{l}\text { Parents with a low level of } \\
\text { education and income }\end{array}$ & $201 / 692=29.05 \%$ & 8.29 & $p=0.00397$ \\
\hline
\end{tabular}




\section{Appendix D}

Table A3. Classes, ratio, Chi2 and $p$ for parents in the second interview: first associated words.

\begin{tabular}{|c|c|c|c|}
\hline Words & Subtotal to Total Ratio & Chi2 & $p$ \\
\hline $\begin{array}{l}{\text { Class } 1^{\prime}} \\
\text { Relating to the salty food repertoire }\end{array}$ & $\begin{array}{l}245 / 1485=16.5 \% \text { of } \\
\text { classified segments }\end{array}$ & & \\
\hline Tomato & $23 / 26=88.46 \%$ & 99.48 & $p<0.0001$ \\
\hline Meat & $33 / 48=68.75 \%$ & 98.31 & $p<0.0001$ \\
\hline Egg & $22 / 26=84.62 \%$ & 89.13 & $p<0.0001$ \\
\hline Sauce & $17 / 17=100 \%$ & 87.04 & $p<0.0001$ \\
\hline Season diversification & $208 / 864=24.07 \%$ & 86.07 & $p<0.0001$ \\
\hline Diversification at 5 months & $153 / 563=27.18 \%$ & 75.04 & $p<0.0001$ \\
\hline $\begin{array}{c}\text { Class 2' } \\
\text { Perceived changes in child's } \\
\text { development }\end{array}$ & $\begin{array}{l}577 / 1485=38.86 \% \text { of } \\
\text { classified segments }\end{array}$ & & \\
\hline Child & $43 / 58=74.14 \%$ & 31.63 & $p<0.0001$ \\
\hline Month & $34 / 47=72.34 \%$ & 22.91 & $p<0.0001$ \\
\hline Curve & $14 / 14=100 \%$ & 22.24 & $p<0.0001$ \\
\hline Weight & $15 / 16=93.75 \%$ & 20.52 & $p<0.0001$ \\
\hline Girl & $20 / 24=83.33 \%$ & 20.31 & $p<0.0001$ \\
\hline Diversification at 5 months $\frac{1}{2}$ & $61 / 70=87.14 \%$ & 72.1 & $p<0.0001$ \\
\hline High social position & $95 / 143=66.43 \%$ & 50.66 & $p<0.0001$ \\
\hline Standards_promotion & $148 / 265=55.85 \%$ & 39.21 & $p<0.0001$ \\
\hline $\begin{array}{l}\text { Class } 3^{\prime} \\
\text { Relating to the sweet food repertoire }\end{array}$ & $\begin{array}{l}435 / 1485=29.29 \% \text { of } \\
\text { classified segments }\end{array}$ & & \\
\hline Buy & $70 / 95=73.68 \%$ & 96.56 & $p<0.0001$ \\
\hline Yogurt & $57 / 71=80.28 \%$ & 93.6 & $p<0.0001$ \\
\hline Compote & $43 / 51=84.31 \%$ & 77.19 & $p<0.0001$ \\
\hline Fruit & $34 / 44=77.27 \%$ & 50.4 & $p<0.0001$ \\
\hline Dessert & $27 / 32=84.38 \%$ & 47.91 & $p<0.0001$ \\
\hline Chocolate & $32 / 45=71.11 \%$ & 39.18 & $p<0.0001$ \\
\hline Standards_distance & $42 / 63=66.67 \%$ & 44.37 & $p<0.0001$ \\
\hline No breastfeeding & $82 / 161=50.93 \%$ & 40.82 & $p<0.0001$ \\
\hline Follow-up_pediatrician & $259 / 709=36.53 \%$ & 34.31 & $p<0.0001$ \\
\hline Sex of child_boy & $235 / 668=35.18 \%$ & 20.31 & $p<0.0001$ \\
\hline $\begin{array}{c}\text { Class } 4^{\prime} \\
\begin{array}{c}\text { Temporal framework of food } \\
\text { socialization }\end{array}\end{array}$ & $\begin{array}{l}228 / 1485=15.35 \% \text { of } \\
\text { classified segments }\end{array}$ & & \\
\hline Wake up & $16 / 16=100 \%$ & 89.17 & $p<0.0001$ \\
\hline Bottle feeding & $27 / 41=65.85 \%$ & 82.74 & $p<0.0001$ \\
\hline Night & $16 / 17=94.12 \%$ & 82.09 & $p<0.0001$ \\
\hline Morning & $29 / 49=59.18 \%$ & 74.9 & $p<0.0001$ \\
\hline Sleep & $13 / 13=100 \%$ & 72.3 & $p<0.0001$ \\
\hline Bedtime & $17 / 21=80.95 \%$ & 70.53 & $p<0.0001$ \\
\hline Time & $19 / 26=73.08 \%$ & 68.85 & $p<0.0001$ \\
\hline Salty type diversification & $196 / 1000=19.6 \%$ & 42.48 & $p<0.0001$ \\
\hline Sex of child_boy & $140 / 668=20.96 \%$ & 57.78 & $p<0.0001$ \\
\hline Follow-up_pediatrician & $141 / 709=19.89 \%$ & 21.46 & $p<0.0001$ \\
\hline Family_Multiparous & $120 / 589=20.37 \%$ & 18.93 & $p<0.0001$ \\
\hline
\end{tabular}




\section{Notes}

1 "Food work" is defined as household and caring work related to food to highlight gender differences in materialist feminist approaches (DeVault 1991; Cairns and Josée 2015; Parsons 2015; O'Connell and Brannen 2016). Our conception of "food work" extends this perspective. We add parental work, as well as relational, affective and emotional work related to meal preparation because it brings additional physical and mental loads in the nurturing activity (Dupuy 2013; Dupuy 2017a; Dupuy et al. 2018b). This addition is relevant in a context favorable to "parental determinism" (Furedi 2002) and to the increase in injunctions to "good parenting" (Martin 2014).

\section{References}

Anderson, Judith V., Deborah I. Bybee, Randi M. Brown, Donna F. McLean, Erika M. Garcia, M. Lynn Breer, and Barbara A. Schillo. 2001. 5 a Day Fruit and Vegetable Intervention Improves Consumption in a Low Income Population. Journal of the American Dietetic Association 101: 195-202. [CrossRef]

ANSES. 2019. Avis De L'anses Relatif À L'actualisation Des Repères Alimentaires Du Pnns-Jeunes Enfants (0-3 Ans). Available online: https:/ / www.anses.fr/fr/content/avis-de-lanses-relatif-\%C3\%A0-lactualisation-des-rep\%C3\%A8res-alimentaires-dupnnsjeunes-enfants-0-3 (accessed on 19 February 2021).

Birch, Leann L. 1987. Children's Food Preferences: Developmental Patterns and Environmental Influences. Annals of Child Development 4: 171-208.

Birch, Leann L. 1990. The control of food intake by young children. The role of learning. In Taste, Experience and Feeding. Edited by Elizabeth D. Capaldi and Terry L. Powley. Washington, DC: American Psychological Association, pp. 116-35.

Birch, Leann L., and Jennifer O. Fisher. 1998. Development of eating behaviors among children and adolescents. Pediatrics 101: 539-49.

Birch, Leann L., and Jennifer O. Fisher. 2000. Mothers' child-feeding practices influence daughters' eating and weight. The American Journal of Clinical Nutrition 71: 1054-61. [CrossRef]

Birch, Leann L., Sheryl Itkin Zimmerman, and Honey Hind. 1980. The influence of social-affective context on the formation of children's food preferences. Child Development 51: 856-61. [CrossRef]

Birch, Leann L., Linda McPhee, B. C. Shoba, Edna Pirok, and Lois Steinberg. 1987. What kind of exposure reduces children's food neophobia? Looking vs. tasting. Appetite 9: 171-78. [CrossRef]

Birch, Leann L., Susan L. Johnson, Graciela Andresen, John C. Peters, and Marcia C. Schulte. 1991. The variability of young children's energy intake. New England Journal of Medicine 324: 232-35. [CrossRef]

Birch, Leann L., Jennifer Orlet Fisher, and Kirsten Krahnstoever Davison. 2003. Learning to overeat: Maternal use of restrictive feeding practices promotes girls' eating in the absence of hunger. The American Journal of Clinical Nutrition 78: 215-20. [CrossRef]

Bourdieu, Pierre. 2000. Esquisse d'une théorie de la pratique. Précédé de trois études d'ethnologie Kabyle. Paris: Seuil. First published in 1972.

Bournez, Marie, Eléa Ksiazek, Sandra Wagner, Claire Kersuzan, Christine Tichit, Severine Gojard, Xavier Thierry, Marie-Aline Charles, Sandrine Lioret, Blandine de Lauzon-Guillain, and et al. 2018. Factors Associated with the Introduction of Complementary Feeding in the French Elfe Cohort Study. Maternal and Child Nutrition 14: e12536. [CrossRef] [PubMed]

Bournez, Marie, Eléa Ksiazek, Marie-Aline Charles, Sandrine Lioret, Marie-Claude Brindisi, Blandine de Lauzon-Guillain, and Sophie Nicklaus. 2019. Frequency of Use of Added Sugar, Salt, and Fat in Infant Foods up to 10 Months in the Nationwide Elfe Cohort Study: Associated Infant Feeding and Caregiving Practices. Nutrients 11: 733. [CrossRef] [PubMed]

Bril, Blandine, Estelle Hombessa-Nkounkou, Jean-François Bouville, and Célina Ocampo. 2001. From milk to adult diet: A comparative study on the socialization of food. Food and Foodways 9: 155-86. [CrossRef]

Brugaillères, Pauline, Claire Chabane, Sylvie Issanchou, and Camille Schwartz. 2019. Caloric compensation ability around the age of 1 year: Interplay with the caregiver-infant mealtime interaction and infant appetitive traits. Appetite 142: 104382. [CrossRef]

Cairns, Kate, and Johnston Josée. 2015. Food and Femininity. London: Bloomsbury.

Cardon, Philippe, Thomas Depecker, and Marie Plessz. 2019. Sociologie de l'alimentation. Malakoff: Armand Colin.

Chiva, Matty. 1979. Comment la personne se construit en mangeant. Communications 31: 107-18. [CrossRef]

Collier, John, and Malcom Collier. 1986. Visual Anthropology: Photography as a Research Method. Albuquerque: University of New Mexico Press. First published in 1976.

Connell, Raewyn. 1987. Gender and Power. Society, the Person and Sexual Politics. Stanford: Stanford University Press.

Cooke, Lucy J., Lucy C. Chambers, Elizabeth V. Añez, and Jane Wardle. 2011. Facilitating or Undermining? The Effect of Reward on Food Acceptance. A Narrative Review. Appetite 57: 493-97. [CrossRef] [PubMed]

Corbeau, Jean-Pierre. 2008. Nourrir de plaisir, Se nourrir de plaisir: De la recommandation à la condamnation. In Nourrir de Plaisir. Edited by Corbeau Jean-Pierre. Cahier n ${ }^{\circ} 13$ de l'OCHA. Paris: OCHA, pp. 154-62.

Corbeau, Jean-Pierre, ed. 2010. Trajectoires alimentaires et parcours de vie. Paris: INPES Éditions.

Depecker, Thomas. 2010. Les cultures somatiques: Rapports au corps et diététique. Revue d'études en agriculture et environnement 91: 153-84.

DeVault, Marjorie L. 1991. Feeding the Family. The Social Organization of Caring as Gendered Work. Chicago: University of Chicago Press.

Dhuot, Raphaël. 2018. La genèse précoce des différences sociales dans les habitudes alimentaires. Ph.D. dissertation, Université Paris-Saclay, Gif-sur-Yvette, France; 596p. 
Diasio, Nicoletta. 2006. Adultes et enfants entre pouvoir et insoumission. In Eléments pour une sociologie de l'enfance. Edited by Régine Sirota. Rennes: Le Sens Social, PUR, pp. 245-55.

Diasio, Nicoletta, and Virginie Vinel, eds. 2017. Corps et préadolescence. Intime, privé, public. Rennes: Le sens social, PUR.

Diasio, Nicoletta, and Marie-Pierre Julien. 2018. Anthropology of Family Food Practices: Constraints, Adjustments, Innovations. Bruxelles: PIE Peter Lang.

Di Santis, Katherine I., Eric A. Hodges, Susan L. Johnson, and Jennifer Orlet Fisher. 2011. The Role of Responsive Feeding in Overweight During Infancy and Toddlerhood: A Systematic Review. International Journal of Obesity 35: 480-92. [CrossRef]

Dubuisson-Quellier, Sophie. 2006. De la routine à la délibération. Les arbitrages des consommateurs en situation d'achat. Réseaux 1: 253-84. [CrossRef]

Dupuy, Anne. 2013. Plaisirs alimentaires. In Socialisation des enfants et des adolescents. Rennes: Presses Universitaires de Rennes; Presses Universitaires François-Rabelais, Coll. Tables des hommes.

Dupuy, Anne. 2017a. Société, culture et alimentation. In Alimentation sous influences. Edited by Boris Cyrulnik. Savigny sur Orge: Philippe Duval, pp. 103-13.

Dupuy, Anne. 2017b. La division sexuelle du travail alimentaire: Qu'est-ce qui change? In Que manger? normes et pratiques alimentaires. Edited by François Dubet. Paris: La Découverte, Recherches, pp. 164-75.

Dupuy, Anne, and Amandine Rochedy. 2018. Socialisations alimentaires et pratiques rituelles durant la petite enfance. Anthropology of Food. Available online: http:/ /journals.openedition.org/aof/8253 (accessed on 28 July 2021).

Dupuy, Anne, Rochedy Amandine, and Charlotte Sarrat. 2018a. Feeding young children with home-made food: Routines, necessary disruptions and production of domestic rituals. In Anthropology of Family Food Practices: Constraints, Adjustments, Innovations. Edited by Nicoletta Diasio and Marie-Pierre Julien. Bruxelles: PIE Peter Lang, pp. 183-215.

Dupuy, Anne, Laurence Tibère, and Stéphanie Goirand. 2018b. Travail alimentaire et délégation éducative. Le cas des assistantes maternelles à domicile. Revue des politiques sociales et familiales 129: 37-50. [CrossRef]

Durkheim, Emile. 1981. Les règles de la méthode sociologique. Paris: PUF. First published in 1894.

Farrow, Claire, and Jackie Blissett. 2006. Maternal cognitions, psychopathologic symptoms, and infant temperament as predictors of early infant feeding problems: A longitudinal study. International Journal of Eating Disorders 39: 128-34. [CrossRef] [PubMed]

Fielding-Singh, Priya. 2017. A Taste of Inequality: Food's Symbolic Value across the Socioeconomic Spectrum. Sociological Science 4: 424-48. [CrossRef]

Fischler, Claude. 1990. L'homnivore. Paris: Odile Jacob.

Fischler, Claude, and Matty Chiva. 1986. Food likes, dislikes and some of their correlates in a sample of French children and young adults. In Measurement and Determinants of Food Habits and Food Preferences. Edited by Joerg M. Diehl and Claus Leitzmann. Report of an EC Workshop. Giessen: EURO NUT, pp. 1-4.

Furedi, Franck. 2002. Paranoïd Parenting. Why Ignoring the Experts May be Best for your Children? A Cappella Books. Chicago: Chicago Review Press.

Garcia, Sandrine. 2011. Mères sous influence. De la cause des femmes à la cause des enfants. Textes à l'appui/Genre \& Sexualité, La Découverte. Paris: Coll.

Gojard, Séverine. 2000. L'alimentation dans la prime enfance. Diffusion et réception des normes de puériculture. Revue française de sociologie 41: 475-512. [CrossRef]

Gojard, Séverine. 2001. Meal schedules in early childhood: A study in contemporary France. Food and Foodways 9: 187-203. [CrossRef]

Gojard, Séverine. 2006. Changement de normes, changement de pratiques? Les prescriptions alimentaires à destination des jeunes enfants dans la France contemporaine. Journal des anthropologues 106-107: 269-85. [CrossRef]

Gojard, Séverine. 2010. Le métier de mère. Paris: La Dispute.

Gottlieb, Alma. 2000. Où sont passés tous les bébés? Vers une anthropologie du nourrisson. In En Substances. Textes pour Françoise Héritier. Edited by Jean-Luc Jamard, Emmanuel Terray and Margarita Xanthakou. Paris: Fayard, pp. 367-85.

Gross, Rachel S., Arthur H. Fierman, Alan L. Mendelsohn, Mary Ann Chiasson, Terry J. Rosenberg, Roberta Scheinmann, and Mary Jo Messita. 2010. Maternal Peceptions of Infant Hunger, Satiety, and Pressuring Feeding Styles in an Urban Latina Wic Population. Academic Pediatrics 10: 29-35. [CrossRef]

Hamelin Brabant, Louise, and André Turmel, eds. 2012. Les figures de l'enfance: Un regard sociologique. Quebec: Presses Inter-Universitaires.

HCSP. 2020. Avis Relatif À La Révision Des Repères Alimentaires Pour Les Enfants Âgés De 0-36 Mois Et De 3-17 Ans. Available online: https: / / www.hcsp.fr/explore.cgi/avisrapportsdomaine?clefr=924 (accessed on 19 February 2021).

Hetherington, Marion. 2017. Understanding infant eating behavior-Lessons learned from observation. Physiology \& Behavior 176: 117-24. [CrossRef]

Hodges, Eric A., Susan L. Johnson, Sheryl O. Hughes, Judy M. Hopkinson, Nancy F. Butte, and Jennifer O. Fisher. 2013. Development of the Responsiveness to Child Feeding Cues Scale. Appetite 65: 210-19. [CrossRef] [PubMed]

Hubert, Annie. 2000. Alimentation et santé: La science et l'imaginaire. Cahiers de Nutrition et de Diététique 35: 353-56. [CrossRef]

Hughes, Sheryl O., Thomas G Power, Teresia M O'Connor, Jennifer Orlet Fisher, and Tzu-An Chen. 2016. Maternal feeding styles and food parenting practices as predictors of longitudinal changes in weight status in hispoanic preschoolers from low-income families. J Obesity 2016: 7201082. [CrossRef]

Lahire, Bernard, ed. 2019. Enfances de classe. De l'inégalité parmi les enfants. Paris: Seuil. 
Lalanne, Michèle, and Laurence Tibère. 2008. Quand les enfants font craquer les modèles alimentaires des adultes. Enfance 60: 271-79. [CrossRef]

Laurier, Eric, and Sally Wiggins. 2011. Finishing the family meal. The interactional organisation of satiety. Appetite 6: 53-64. [CrossRef]

Le Pape, Marie-Clémence, and Marie Plessz. 2017. C'est l'heure du petit-déjeuner? Rythme des repas, incorporation et classe sociale. L'Année sociologique 67: 73-106. [CrossRef]

Lhuissier, Anne, Christine Tichit, France Caillavet, Philippe Cardon, Ana Masullo, Judith Martin-Fernandez, Isabelle Parizot, and Pierre Chauvin. 2013. Who still eats three meals a day? Findings from a quantitative survey in the Paris area? Appetite 63: 59-69. [CrossRef]

Martin, Claude, ed. 2014. Etre un bon parent. Une injonction contemporaine. Rennes: Presses de l'EHESP.

Mauss, Marcel. 1936. Les techniques du corps. Journal de Psychologie 32: 365-86.

McNally, Janet, Siobhan Hugh-Jones, Samantha Caton, Carel Vereijken, Hugo Weenen, and Marion Hetherington. 2016. Communicating Hunger and Satiation in the First 2 years of Life: A Systematic Review. Maternal and Child Nutrition 12: 205-28. [CrossRef]

McNally, Janet, Siobhan Hugh-Jones, and Marion Hetherington. 2020. "An invisible map"-maternal perceptions of hunger, satiation and 'enough' in the context of baby led and traditional complementary feeding practices. Appetite 148: 104608. [CrossRef]

Monnery-Patris, Sandrine, Natalie Rigal, Audrey Peteuil, Claire Chabanet, and Issanchou Sylvie. 2019. Development of a new questionnaire to assess the links between children's self-regulation of eating and related parental feeding practices. Appetite 138: 174-83. [CrossRef] [PubMed]

Moura, Andrea Ferreira, and Jessica Aschemann-Witzel. 2020. A downturn or a window of opportunity? How Danish and French parents perceive changes in healthy eating in the transition to parenthood. Appetite 150: 104658. [CrossRef] [PubMed]

Nicaise, Sarah, Martine Court, Christine Mennesson, and Emmanuelle Zolesio. 2019. Vêtements, soins et alimentation: L'inscription corporelle des différences sociales. In Enfances de classe. De l'inégalite̋ parmi les enfants. Edited by Bernard Lahire. Paris: Seuil, pp. 1137-57.

Nicklaus, Sophie, Vincent Boggio, and Sylvie Issanchou. 2005. Food choices at lunch during the third year of life: High selection of animal and starchy foods but avoidance of vegetables. Acta Paediatrica 94: 943-51. [CrossRef]

Nicklaus, Sophie, Marie Bournez, Eléa Ksiazek, Marion Taine, Barbara Heude, Jeremy Botton, Anne Forhan, Marie-Aline Charles, and Blandine de Lauzon-Guillain. 2019. Débuter la diversification alimentaire: Une décision influencée par la croissance de l'enfant? Colloque International Beco "Bébé, petite enfance en contextes". Toulouse: Mai.

O'Connell, Rebecca, and Julia Brannen. 2016. Food, Families and Work. London: Bloomsbury.

Ochs, Elinor, and Merav Shohet. 2006. The cultural structuring of mealtime socialization. Next Directions for Child and Adolescent Development 111: 35-49. [CrossRef]

Odgen, Jane, Rebecca Reynolds, and Andrea Smith. 2006. Expanding the concept of parental control. A role for overt and covert control of children's snacking behavior? Appetite 47: 100-6.

Parsons, Julie M. 2015. Gender, Class and Food: Families, Bodies and Health. London: Palgrave.

Perez-Escamilla, Rafael, Sofia Segura-Pérez, and Megan Lott. 2017. Feeding Guidelines for Infants and Young Toddlers. A responsive parenting approach. Nutrition Today 52: 223-31. [CrossRef]

Pérez-Escamilla, Rafael, Sofia Segura-Pérez, and Victoria Hall Moran. 2019. Dietary guidelines for children under 2 years of age in the context of nurturing care. Maternal and Child Nutrition 15: e12855. [CrossRef] [PubMed]

Piette, Albert. 2013. Au cœur de l'activité, au plus près de la présence. Réseaux 182: 57-88. [CrossRef]

Pliner, Patricia. 1994. Development of measures of food neophobia in children. Appetite 23: 147-63. [CrossRef]

Poulain, Jean-Pierre. 2002. Sociologies de l'alimentation: Les mangeurs et l'espace social alimentaire. Paris: PUF.

Poulain, Jean-Pierre. 2005. S'adapter au monde ou l'adapter? L'alimentation en mouvement, des grandes migrations au tourisme. Diasporas, Histoire et sociétés 7: 13-30.

Poulain, Jean-Pierre. 2009. Sociologie de l'obésité. Paris: PUF.

Poulain, Jean-Pierre. 2017. The Sociology of Food. Etaing and the Place of Food in Society. Translated by Augusta Dörr. London: Bloomsbury Publishing.

Régnier, Faustine, and Ana Masullo. 2009. Obésité, goûts et consommation. Intégration des normes d'alimentation et appartenance sociale. Revue Française de Sociologie 50: 747-73. [CrossRef]

Remy, Eloïse, Sylvie Issanchou, Claire Chabanet, Vincent Boggio, and Sophie Nicklaus. 2015. Impact of Adiposity, Age, Sex and Maternal Feeding Practices on Eating in the Absence of Hunger and Caloric Compensation in Preschool Children. International Journal of Obesity 39: 925-30. [CrossRef]

Ricroch, Layla, and Thibaut de Saint Pol. 2012. Le temps de l'alimentation en France. INSEE Première 1417: 1-4.

Rigal, Nathalie, Marie Laure Frelut, Marie Odile Monneuse, Claude Marcel Hladik, Bruno Simmen, and Patrick Pasquet. 2006. Food neophobia in the context of a varied diet induced by a weight reduction program in massively obese adolescents. Appetite 46 : 207-14. [CrossRef]

Rochedy, Amandine, and Jean-Pierre Poulain. 2015. Approche sociologique des néophobies alimentaires chez l'enfant. Dialogue 209: 55-68. [CrossRef]

Rouré, H., and Max Reinert. 1993. Analyse d'un entretien à l'aide d'une méthode d'analyse lexicale. In JADT. Paris: ENST, pp. 418-28.

Schwartz, Camille, Petra Scholtens, Amandine Lalanne, Hugo Weenen, and Sophie Nicklaus. 2011. Development of Healthy Eating Habits Early in Life: Review of Recent Evidence and Selected Guidelines. Appetite 57: 796-807. [CrossRef] 
Serre, Delphine. 1998. Le bébé "superbe": La construction de la déviance corporelle par les professionnel(le)s de la petite enfance. Sociétés contemporaines 31: 107-27. [CrossRef]

Shloim, Netalie, Irfan Shafiq, Pam Blundell-Birtill, and Marion Hetherington. 2018. Infant hunger and satiety cues during the first two years of life: Developmental changes of within meal signaling. Appetite 128: 303-10. [CrossRef]

Skafida, Valeria. 2013. The family meal panacea: Exploring how different aspects of family meal occurrence, meal habits and meal enjoyment relate to young children's diets. Sociology of Health $\mathcal{E}$ Illness 35: 906-23. [CrossRef]

Skinner, Jean D., Betty Ruth Carruth, Kelly Houck, James Moran, A. Ann Reed, Frances Coletta, and Dana Ott. 1998. Mealtime communication patterns of infants from 2 to 24 months of age. Journal of Nutrition Education 30: 8-16. [CrossRef]

Southerton, Dale. 2006. Analysing the temporal organization of daily life: Social constraints, practices and their allocation. Sociology 40: 435-54. [CrossRef]

Tibère, Laurence, Amandine Rochedy, and Charlotte Sarrat. 2018. Goûter en France. In Dictionnaire des cultures alimentaires. Edited by Jean-Pierre Poulain. Paris: PUF, pp. 682-86.

Tibère, Laurence, and Anne Dupuy. 2021. L'apprentissage de la régulation de la faim au cours de la petite enfance. Ajustements autour du dessert et du jeu. In Socialisation familiale des jeunes enfants. Edited by Anne Dupuy, Christine Mennesson, Michelle Kelly-Irving and Chantal Zaouche Gaudron. Collection Enfance \& parentalité. Toulouse: Editions ERES, 264 p, pp. $133-47$.

Turmel, André. 2008. Une sociologie historique de l'enfance. Pensée du développement, catégorisation et visualisation graphique. Québec: Presses de l'université Laval.

Wiggins, Sally. 2019. Moments of Pleasure: A Preliminary Classification of Gustatory mmms and the Enactment of Enjoyment during Infant Mealtimes. Frontiers in Psychology 10: 1404. [CrossRef]

Yuan, Wen Lun, Christine Lange, Camille Schwartz, Christophe Martin, Claire Chabanet, Blandine de Lauzon-Guillain, and Sophie Nicklaus. 2016. Infant Dietary Exposures to Sweetness and Fattiness Increase During the First Year of Life and Are Associated with Feeding Practices. Journal of Nutrition 146: 2334-42. [CrossRef] 